\title{
The Cloud on the Way \\ 1860
}

(LETTERS 1123 TO 1189)

See, before us, in our journey, broods a mist upon the ground;

Thither leads the path we walk in, blending with that gloomy bound.

... One by one we miss the voices which we loved so well to hear;

One by one the kindly faces in that shadow disappear....

-"The Cloud on the Way," January 1860.

With BUt ONE EXception, the few poems Bryant wrote in 1860 sounded an elegiac tone: "The Cloud on the Way," "The Tides," and "Waiting by the Gate." This reflected in part sorrow at the recent loss of his friends Charles Leupp, Theodore Sedgwick III, and Washington Irving, and that in February of his little grandson Alfred Godwin, the first death in his immediate family since that of his mother fourteen years earlier. But he shared as well a national sense of foreboding at the execution of John Brown, and at the near chaos in Congress as the bitter sectional struggle over the choice of a Speaker dragged on. Although that issue at last reached a compromise acceptable to the North, there were constant rumblings in both House and Senate prefiguring southern secessions, and southern threats that the election of a Republican President would shatter the Union.

The choice of a Republican candidate was as yet uncertain when in February Bryant and other leading New York Republicans including Hamilton Fish, David Dudley Field, and John Jay-all advisers to the Young Men's Central Republican Union and firmly opposed to the nomination of Senator William H. Seward-raised funds to bring Abraham Lincoln of Illinois before an audience of fifteen hundred of the city's influential citizens at Manhattan's new Cooper Union. This was Lincoln's first appearance in the Northeast. Bryant, chosen by the meeting to preside, called him a "gallant soldier of the political campaign of 1856 " who would have gone to the Senate in 1858 had it not been for an "unjust apportionment law," concluding, "I need only to pronounce the name of Abraham Lincoln of Illinois ... to secure your profoundest attention."

Lincoln addressed his audience with a carefully reasoned eloquence which brought his dignified audience, termed by the New York Tribune the largest "assemblage of the city's brains and character ... since the days of Clay and Webster," to their feet in a shouting ovation. This speech, called by Allan Nevins "a landmark in the thought of the period," contributed largely to Lincoln's nomination three months later. He was reported afterward to have been eager to learn what Bryant had written of his address in the Evening Post, and to have remarked, "It is worth a visit from Springfield Illinois to New York to make the acquaintance of such a man" as Bryant. The Evening Post's edi- 
torial comment the next day, though not so hyperbolic as that of the Tribune"No man ever before made such an impression on his first appeal to a New York audience"-was more to the point: "It is wonderful how much a truth gains by a certain mastery of clear and impressive statement."

Until Lincoln's selection in May to lead the Republican ticket, Bryant wrote little editorially of his candidacy, but left no doubt thereafter of his support. "The Convention could have made no choice," he wrote, "which, along with so many demonstrations of ardent approval, would have been met with so few expressions of dissent. ... Whatever is peculiar in the history and development of America, whatever is foremost in its civilization, whatever is good in its social and political structure, finds its best expression in the career of such men as Abraham Lincoln. ... It is written on the tablet of destiny that Lincoln is to be the next President of the United States."

During the first half of the year, until John Bigelow returned from Europe in June, Bryant was again the sole responsible editor of the newspaper, for William S.Thayer had become ill in January and failed to return to the office. But the Evening Post's influence grew steadily as the organ of Republican resistance to the spread of slavery. In January Senator King remarked that it was "doing its whole duty as it did in 55 and 56 " by the party. Years later George Haven Putnam, who had been present at the Cooper Union address, regretted that Bryant's "fame as a poet has possibly eclipsed the importance of his service as an editorial teacher ... and as a wise and patriotic leader of public opinion."

Bryant's concern with politics in this crucial year spared him little leisure for creative writing. Although the handful of poems he did produce drew praise from friends, particularly for "The Cloud on the Way," which Bigelow called "one of the most impressive poems I ever read," it was his commemorative appreciation of Washington Irving before the New-York Historical Society which drew the widest acclaim. This response reflected in part a universal affection for the genial essayist and creator of a native mythology who had been the first American author to gain wide respect abroad. It was equally a tribute to its author's felicitous treatment of such a subject, which had been evidenced earlier in his orations on Thomas Cole and Fenimore Cooper, and which, with the Irving speech, established him as the memorialist of his literary generation. Dana found in the Irving address "that completeness which shows a man to have full possession of his subject." Bigelow called it "the model of an eloge." Even Seward, though smarting under the Evening Post's denials of his fitness for the presidency, had the grace to salute this "most wonderful elogium, ... a monument of American literature." During Bryant's visit to Boston in October, Longfellow made a strenuous effort to persuade him to dine with the exclusive Saturday Club of New England authors. President Robert Winthrop of the Massachusetts Historical Society "cherished" an inscribed copy of the address, and notified Bryant of his unanimous election to the honorary membership in that organization lately held by Irving.

Though Bryant did not visit his brothers in Illinois that year, he continued to buy through his brother John farms and farmland in and near Princeton, adding over three hundred acres to his considerable holdings there. An item of family interest was the appointment of Cyrus Bryant's son Cullen as a West Point cadet. 
Because scarcely any of John Bryant's letters to Cullen during 1859-1860 seems to have survived, it remains uncertain to what degree John may have encouraged his brother's advocacy of Lincoln as presidential nominee. John had been an associate of Lincoln's in the Illinois legislature as well as a founder of the state's Republican party, and there is no doubt of his enthusiasm in supporting Lincoln's candidacy. The day after the November election, he wired the winner, "Bureau Co. sends greetings with twenty three hundred majority for Lincoln Lovejoy and Liberty."

Whatever impelled him toward support of Lincoln, Cullen Bryant made it his chief political concern during the second half of the year, gradually assuming the role of confidential admonitor. Assuring the candidate in a June letter that the country was to be congratulated on his nomination, achieved without "pledges or engagements," and that the people "are satisfied with you as you are, and they want you to do nothing at present but allow yourself to be elected," he warned, they "want you to make no speeches write no letters as a candidate, enter into no pledges, make no promises, nor even give any of those kind words which men are apt to interpret into promises." He was confident of Lincoln's coming election, and wanted him to take office with "every advantage for making the most judicious and worthy appointments and lending [his] aid to the wisest and most beneficial measures." Lincoln returned thanks for "the additional strength your words give me."

In August Bryant sent a trusted reporter to Springfield, ostensibly for an interview, but equally to feel out the extent to which Lincoln might have made commitments of the kind Bryant had warned against. Shortly before the election he became alarmed at an effort by New York politicians close to Seward as well as to "Wall Street" to persuade the candidate to make a "soothing speech" to "quiet the public mind" by temporizing with the South on the issues of slavery and secession, and he urged Lincoln to stand firm against their pressure. A few days after Lincoln's election on November 6 Bryant tried to prevent a rumored choice of Seward to the first position in his cabinet by urging on the President-elect the appointment of Salmon P. Chase of Ohio as Secretary of State. And on Christmas day-five days after South Carolina had seceded from the Union-he warned again that any concession to the slave interests would "disgust and discourage the large majority of Republicans in this state and cool their interest in the incoming administration down to the freezing point." That month John Murray Forbes hailed Bryant's "wise and steady advice to the Republican party to keep firm and quiet." 
1123. To Edwin D. Morgan ${ }^{1}$

My dear sir.

New York January 27, 1860.

The bearer of this is Mr. John Cockle of Brooklyn, ${ }^{2}$ an old free soil democrat, a thorough Republican, a man of sense, integrity and high respectability, whom I have known for many years. I give him this letter, and state these things in his favor, that you may know what credit to give to such communications as he may make to you in your official capacity.

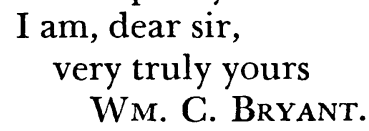

MANUSCRIPT: NYSL ADdREss: To Governor Edwin D. Morgan.

1. See 943.1 .

2. Not further identified.

1124. To John Jay ${ }^{1}$

My dear sir.

New York January 28, 1860.

I have just found your article in reply to the two Episcopalians, and if it had been of reasonable length would have put it in type immediately. Just now we begin to be pressed for advertisements-and we cannot leave out the proceedings of Congress, nor the fires, nor the doings of the legislature, and we have a dozen columns or less already in type-matter pressing for admission and getting stale- Can you not in mercy condense your reply? I send it that you may see if this can be done. Twice as many would read it if it were twice as short. Do this and I will state the cause of delay as fully as you please. ${ }^{2}$

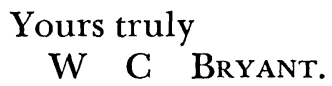

MANUSCRIPT: CU ADDRESS: J. Jay Esqre.

1. See 640.2 .

2. Early in 1860 a New York Episcopal Church convention had refused to entertain resolutions offered by Jay deploring the slave trade, bringing upon its members condemnation by the New York Tribune and other journals. On January 18 and 19 the EP printed letters from "Rector" and "A High Church Abolitionist," calling Jay a "pertinacious and persistent friend of the Negro" who had always been "good-humouredly treated," but was the sort "who are never satisfied that they can do anything unless they can do it on the platform." No reply from Jay has been found in the EP for the month following these criticisms. 
1125. To Brantz Mayer ${ }^{1}$

My dear sir.

New York January 29 $9^{\text {th }}, 1860$.

Miss Eveneline J. Kinne, the daughter of Judge Kinne of this state, lately deceased, has desired of me a letter to some person in Baltimore whose advice would be valuable to her in regard to the disposition of the law books of which her father was the author. ${ }^{2}$

I hope you will not disapprove of the liberty I have taken in giving her this note to you, and that you will kindly counsel her in what manner she should proceed. With the reputation of her father's works the fruit of vigenti annorum lucubrationes, ${ }^{3}$ you are already familiar.

\section{I am sir}

very truly yours

W. C. BRyant.

MANUSCRIPT: UVa ADDRESS: Mr. Brantz Mayer.

1. Brantz Mayer (1809-1879), a Baltimore lawyer and a founder of the Maryland Historical Society, wrote books on Mexican and Maryland history.

2. Asa Kinne (d. 1859?) edited Kinne's Quarterly Law Compendium, and selections from Blackstone's and Kent's Commentaries.

3. "Twenty years of night study."

1126. To John Bigelow

Mr dear Mr. Bigelow

New York February $6 \quad 1860$

I have just got your letters of the 12th and 18th of January and another of a still later date. That from Montpelier was a most interesting one and I immediately put it in type and the letter respecting the Treaty of Commerce between France and England was a perfect piece of luck. ${ }^{1}$ I shall send off copies of the paper as you desire, and a copy of the semiweekly regularly to No 4 Rue de Berri.

Your letters respecting the policy of the Emperor are eagerly read and much talked of. Those on literary subjects, I am afraid frighten people by their length. The first sell the paper; the others I cannot find have caused the sale of a single one. That of $M$. Ste Beuve, caused no remark whatever, except that the subject of Beranger had been exhausted in your own letters written previously. I read both what related to Beranger and what related to Buffon with much interest, ${ }^{2}$ and so did a few others, but I cannot learn that they attracted much attention from the public. For a daily paper they were rather long, but perhaps that was not the main difficulty. The public at large here knows very little of the history or personal character of either 
of these personages, and what is old relating to them, has in the eyes of the mass of readers here as much novelty as what is just brought to light; but they are not familiar enough with their works to have that craving for anecdotes of their lives conversation and correspondence which they have in the case of men distinguished in English literature. You will pardon me for speaking so frankly but it is just what you would say if you were here.

You refer to something which Mr. Thayer wrote you about my differing with you in the view you took of the rumored refusal of Great Britain to take part in the European Congress without some assurance that the independence of Central Italy should be maintained. My objection was stated in a letter to yourself $-{ }^{3}$ but circumstances have since occurred which put another face on the matter, and it would serve no purpose to discuss the question now. I should never have thought, however, of keeping your letter out of the paper. It was read with general interest, and many persons concurred in its views, Mr. Pell for example, ${ }^{4}$ who is a great Napoleonist. I have no [set?] objection to Napoleon's doing as much good as he can, whether in the cause of commercial or personal liberty notwithstanding his crimes.

We are in a bad plight here in the office. Mr. Thayer has been confined for six weeks or more with an inflammation of the lungs. He is better but has a bad cough yet, and I am afraid the doctor will kill him with iron. Godwin's mother has been very ill with an ulcerated leg; it was amputated, she sank away, and died in a few days; ${ }^{5}$ this kept him away from the office a while; and now he is kept at home by a rheumatic fever-though he is doing better at last. For my own part I have for several days had one eye blocked up by a very bad stye, but I now see daylight again. I have attended, however, at the office constantly and kept the battle going. I am afraid we shall have no such good luck as to see Governor Wise nominated for President by the democratic party. The northern democrats it is certain do not expect it, and profess to be quite ashamed of him. In fact he has made so ridiculous a figure in the eyes of the whole country that he would be the easiest candidate to beat that I can possibly think of. ${ }^{6}$

This is a very unhealthy winter. Violent colds, fevers, bronchitis, scarlet fever, the malignant sore throat, or dip[h]theria, rheumatisms, \&c prevail. My wife is confined with the worst cold she ever had. Fanny's youngest child but one has that fatal distemper the diphtheria. Mr. Tweedy ${ }^{7}$ was made childless by that disease last winter at Albany. It is perhaps well that you have your little ones at such a distance from the spot where it rages.

My kind regards to Mrs. Bigelow. Please make my particular acknowledgments to Mr. Cobden. ${ }^{8}$ I shall write to him when I get time.

I am sir very faithfully yours

W G Bryant. 
MANUSCRIPT: NYPL-GR DOCKETED: Mr Bryant. PUBLISHEd (in part): Life, II, 133.

1. Bigelow's letter dated at Paris on January 18, 1860 (NYPL-BG), enclosed two letters for the $E P$; that dated at Montpelier, January 11, 1860, was printed on February 6; the second was evidently that from Richard Cobden to Bryant of January 12, 1860, quoted in Life, II, 131-132. See Bigelow to Bryant, February 28, 1860, NYPL-BG.

2. An unsigned letter from the French literary historian Charles Augustin SainteBeuve (1804-1869) appeared in the EP on January 26 under the caption "Literary Matters in France."

3. Letter 1119.

4. Alfred Pell; see 329.7, 920.3.

5. Martha Parke Godwin, Mrs. Abraham Godwin (d. 1859).

6. As Democratic governor of Virginia, Henry Alexander Wise (1806-1876) had greatly exaggerated the threat to the South from John Brown's raid of October 16, 1859, on Harper's Ferry, contributing to national hysteria over Brown's execution. He had further compromised his credibility by attacking the national administration and other elements of his own party. Nevins, Emergence of Lincoln, II, 42, 92, 105, and passim.

7. Possibly Edmund Tweedy of Albany, New York, and Newport, Rhode Island, whose wife Mary Temple Tweedy was the novelist Henry James's "Aunt Mary." See Henry James: Letters, ed. Leon Edel (Cambridge: The Belknap Press of Harvard University Press, 1974), I, 21, and passim.

8. Cobden's letter (Note 1) reported on his negotiations for a commercial treaty between England and France. In writing Bryant on January 18, Bigelow had said that Cobden wished his letter to be considered confidential.

1127. To John Bigelow

Dear Mr. Bigelow:

New York, Feb. 20, 1860.

I am not much disappointed by the loss of M. Ste. Beuve's letters. ${ }^{1}$ He is a brilliant writer, but much of French brilliancy disappears in translation, and I am not certain that a Frenchman can write good letters for an American newspaper.

It does not seem to me that the outlay of the correspondence you have planned will ever be returned to us, but if you think differently I would have you try it. The letters I am sure will not be read with the interest that your own have been. A clever man might gather, it appears to me, both literary and scientific matter from the French publications, matter as interesting as a Frenchman in Paris could possibly furnish, and put it into a shape better proportioned to our space and more attractive for general readers. Do not, however, let me stand in the way of any project of the kind which appears to you to promise well. The trial will shew.

As to the candidate for the Presidency, I do not recollect that I gave an opinion as to who would not get the nomination. I find that Bates is more and more talked of for the Republican Candidate. ${ }^{2} \mathrm{He}$ is said, for example, to be the man who can carry Illinois against Douglas by bringing out a large number of old whigs living in the middle of the state-originally from the slave states. The probability-rather let me say the chance that Douglas will be nominated by his party seems to increase. The great reason 
for believing that he will be nominated is that he is their strongest candidate, and to that idea their minds are opening. There is not the slightest prospect of the nomination of Wise. Nine tenths of the democratic party regard the idea as absolutely ludicrous.

Mr. Seward is not without his chances of a nomination, though some of your friends here affirm that he has none. He is himself, I hear, very confident of getting it. While the John Brown excitement continued, his prospects improved, for he was the best abused man of his party. Now that he is let alone his stock declines again and people talk of other men. For my part I do not see that he is more of a representative man than a score of others of our party. The great difficulty which I have in regard to him is this, that by the election of a Republican President the slavery question is settled, and that with Seward for President, it will be the greatest good-luck, a special and undeserved favor of Providence, if every honest democrat of the Republican party be not driven into the opposition within a twelvemonth after he enters the White House. There are bitter execrations of Weed and his friends passing from mouth to mouth among the old radical democrats of the Republican party here. I suppose Weed never behaved worse than now-and his conduct alarms the best men here-they think it an omen of what we may expect from Seward's administration. We have a shamefully corrupt legislature.

Captain Schultz ${ }^{3}$ is very anxious that you should return and electioneer for Seward's nomination. I must say frankly that I would prefer that the question should be left to the convention. both.

... My wife and daughter desire to be cordially remembered to you

$$
\begin{aligned}
& \text { Yrs truly } \\
& \text { [signature not printed] }
\end{aligned}
$$

MANUSCRIPT: Unrecovered TEXT: Bigelow, Retrospections, I, 252-253.

1. Bigelow's attempts to engage Sainte-Beuve as a regular literary contributor to the EP had failed; the French critic thought himself too old and infirm to write for the press on such a basis. Bigelow to Bryant, London, February 3, 1860, NYPL-BG.

2. Edward Bates (1793-1869), Missouri lawyer and former congressman, was favored in the Border States as a Republican presidential candidate. Later, in 1861-1864, he was Attorney General in the Lincoln cabinet.

3. Possibly Jackson S. Schultz, a New York leather merchant who became president of the Union League Club in 1870.

1128. To John W. Edmonds ${ }^{1}$

My dear sir.

New York Feb. 221860.

I hesitate about publishing your letter ${ }^{2}$ for this reason. Mr. [Robert Dale] Owen-who is a spiritualist-informs me that Harris has aspersed the 
American spiritualists in grossest manner and in the most wholesale terms, and Mr. Owen is recently from England where he became acquainted with what Harris is doing. The charges Harris makes I understand are of the foulest nature. ${ }^{3}$

I think he had better be let alone, unless he is to be shown up as a slanderer.

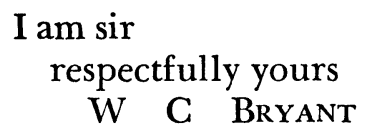

MANUSCRIPT: Indiana University Library ADDRESS: Hon. J. W. Edmonds.

1. See 492.4 .

2. Unrecovered.

3. Thomas Lake Harris (1823-1906), eccentric English-born Universalist clergyman, aspiring poet, and founder of a socialist colony, first in New York and later in California, was notorious a few years after this for having made a "spiritual slave" of the English travel writer and mystic Lawrence Oliphant (1829-1888). Near the end of his life, Oliphant married a daughter of Robert Dale Owen. In 1859-1860 Harris, then editor of the spiritualistic journal The Herald of Light, made a lecture tour of England, in response to a divine call to preach "the Breath of God in Man and Humane Society." His collected writings, published thirty years later, did not include this "wonderful series of sermons," since he felt their use was "over and done with." See Arthur A. Cuthbert, The Life and World-Work of Thomas Lake Harris (Glasgow: C. W. Pierce, 1908), pp. 182-183.

1129. To G[eorge?] W. Porter ${ }^{1}$

My dear sir.

New York February 23d 1860.

I thank you for the very kind expression of sympathy in your letter, ${ }^{2}$ which has just been put into my hands. Mrs. Bryant and my daughter also desire to make their grateful acknowledgments.

We all pray that you and Mrs. Porter, who have young children growing up around you, may be spared an affliction like that which has befallen us. ${ }^{3}$

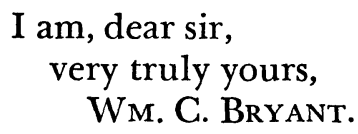

MANUSCRIPT: YCAL ADDRESS: Revd. G. W. Porter.

1. Presbyterian minister in Manhasset, Long Island. See Letters 1440, 1475.

2. Unrecovered.

3. The death of Bryant's second grandson, Alfred Godwin, born in 1855. See Letters 1126 and 1146. 


\section{To Christiana Gibson}

My dear Miss Gibson.

New York Feb. 25. 1860.

My wife and I are alone this evening, and she bids me say, that if you are sure that you have no better way to employ yourself, you would do her, and me also, the greatest favor in the world by coming and sitting an hour with us. Margarita ${ }^{1}$ will wait and come with you, and I will see you home.

Very truly yours

W. C. BRyant.

MANUSCRIPT: DuU AdDREss: Miss Christiana Gibson.

1. Apparently a servant of the Godwins'.

1131. To John Howard Bryant

Dear Brother.

New York March 2d 1860.

Mr. Henderson has answered the business part of your letter. ${ }^{1}$ The seven thousand dollars we are willing to take; the other three we prefer to leave to somebody else, not liking to make a loan for so long a time.

My wife and daughter strongly advise your wife and sister to have the silk dresses made up for Harriet and her sister. They do not think the flounces at all gay. Flounces are not thought so here. Women twice as old as your wife and her sister wear them; nor do I think Mrs. Grundy will make much noise about them in Princeton. If she should, let her. Who cares for Mrs. Grundy? ${ }^{2}$

We are all pretty well. My wife is quite smart again, and goes out every day. She walked with me to church last Sunday. Fanny and her children are well. Godwin has just begun to go to the office again.

Abraham Lincoln made quite a stir here the other evening. The audience was crowded listened attentively and applauded vehemently. ${ }^{3}$

For a few days past the weather has been close and foggy melting all the ice and making the roads deep with mud. Today is a bright springlike day, and we think the winter is over and that the roads will be settled and firm in a short time.

Remember me kindly to your family. My wife and daughter desire their best regards to you all-

\section{Yours affectionately \\ W G Bryant.}

MANUSCRIPT: Wellesley College Library ADDREss: Jno H Bryant Esqre.

1. Their letters are unrecovered, but see Letter 1025 .

2. The symbol of conventional English propriety in the comedy Speed the Plough (1798) by Thomas Morton (1764?-1838). This play was often performed in New York, 
following its first production there in 1800. George C. D. Odell, Annals of the New York Stage, 15 vols. (New York: Columbia University Press, 1931), passim.

3. Bryant's terse comment gives no hint of his part in bringing Lincoln, for the first time, before an influential eastern audience, thus giving him the chance to deliver one of the most telling speeches in his 1860 campaign for the Republican nomination for the presidency. Engaged at first to lecture at Henry Ward Beecher's Plymouth Church in Brooklyn, the Illinois lawyer found himself scheduled instead by the Young Men's Central Republican Union-of which Bryant was an "Advisor"-to make a major political statement in New York's new Cooper Union. An audience of 1,500 political and civic leaders chose Bryant to preside over the meeting on February 27. His introductory remarks were printed the next day in the $E P$ :

It is a grateful office that I perform in introducing to you an eminent citizen of the West, hitherto known to you only by reputation, who has consented to address a New York assembly this evening. A powerful auxiliary, my friends, is the great West in that battle which we are fighting in behalf of freedom against slavery and in behalf of civilization against barbarism, for the occupation of some of the fairest regions of our continent now first opened to colonization. [applause.] I recognize an agency higher and wiser than that of man, in causing the broad and fertile region which forms the northern part of the valley of the Mississippi to be rapidly filled with a population of hardy freemen, who till their own acres with their own hands, and who would be ashamed to subsist by the labor of slaves. [applause.] These children of the West form a living bulwark against the advance of slavery, and from them is recruited the vanguard of the mighty armies of liberty. [Loud applause.] One of them I present to you this evening, a gallant soldier of the political campaign of 1856 , [applause] in which he rendered good service to the Republican cause, and the great champion of that cause in Illinois two years later, when he and his friends would have won the victory but for the unjust apportionment law, by which a minority of the population are allowed to elect a majority of the legislature. I need only to pronounce the name of Abraham Lincoln of Illinois-[loud cheers]-I have only to pronounce his name, to secure your profoundest attention.

Lincoln's address was a closely reasoned constitutional argument for the restriction of slavery. The next day the New York Tribune remarked, "No man ever before made such an impression on his first appeal to a New York audience," and Bryant commented in a leading EP editorial, "It is wonderful how much a truth gains by a certain mastery of clear and impressive statement." EP, February 28, 1860; Nevins, Emergence of Lincoln, II, 183-188; James A. Briggs, An Account of Hon. Abraham Lincoln Being Invited to Give an Address in Cooper Institute, N. Y. February 27, 1860, Together with Mr. Bryant's Introduction and Mr. Lincoln's Speech (Putnam, Connecticut, 1915), pp. 1-5. Briggs's version of Bryant's remarks often departs from the EP text, which is presumably the more authentic.

One member of Lincoln's Cooper Union audience credits Bryant with the initiative which brought the Illinois lawyer into national prominence as an alternative to the leading candidate for the Republican nomination for the presidency, William $\mathbf{H}$. Seward. George Haven Putnam (1844-1930), son and successor of publisher George P. Putnam, recalled many years later that Bryant, "a patriotic and unselfish leader of public opinion," brought together a group of influential New York political leaders to invite Lincoln to speak in the metropolis and persuaded them to finance his trip to the East. "It is well," Putnam wrote, "that Americans should remember the valuable service rendered by William C. Bryant in helping to bring about the selection as the leader, not only of the new party, but of all Americans who fought and worked to save the republic, the great Captain, Abraham Lincoln." Rufus Rockwell Wilson, Intimate Memories of Lincoln (Elmira, New York: Primavera Press, 1945), pp. 256-260. 


\section{To John Bigelow}

Dear Mr. Bigelow.

Both Mr. Henderson and myself are sorry that you should have been disappointed in regard to the office occupied by Mr. Eckel. ${ }^{1}$ We both supposed that you desired merely a place to deposite the articles which might arrive for you from France, and we drew this conclusion from something you said in one of your letters about storing some boxes there which were to be sent on before you. If you had intimated the purpose for which you wanted the room it would have been kept for you. But inasmuch as it was no place for goods, and as moreover, we could not deposite in it the boxes which should first arrive, and finally as Mr. Eckel when he heard it was encouraged to believe that he might have it another year and would have been much disappointed if he did not get it, I concurred with Mr. Henderson in letting him have it. Yet the understanding with Mr. Eckel did not amount to an engagement and we should have obliged him to evacuate, if we had not imagined that the room was not suitable for the purpose you had in view and therefore you must be under some misapprehension in regard to it.

You have this to console you in the meantime, that, if you have been disappointed, another person has been saved from disappointment, which is the next best thing to being saved from disappointment yourself, and if looked at from a Christian point of view quite equal to it.

We have had an unhealthy winter. Several persons of note have gone. Stephen Whitney is not only dead but forgotten. ${ }^{2}$ The clergy trooped to his funeral like crows to a dead horse; but he gave them not a penny by his will-neither to them nor their institutions. George Wood, you see, has followed him..$^{3}$ All the old people will, I suppose, have died off by and by, and only young men be left in the world, and then the day of great reforms will arrive. They are wanted-that is the reforms. The present legislature has the reputation of being the most corrupt that we have had for a long time. People begin to grumble about your friend Governor Morgan and say that he is trying to manage with a view of being made United States Senator.

The attempt to put forward Bates as the Republican candidate for President causes some discussion and some feeling. It seems to me, as at present advised, that his friends will hardly be able to make him enough a Republican to induce our party to take him up. The Blairs you know are zealous in his favor-but we have been beaten already by a candidate nominated by the Blairs.

At the office we are getting on as well as we could expect. The old trouble of too many advertisements and too little reading matter has returned upon us. There is a fight every day between the editorial room and 
the composing room, with Dithmar the sturdy friend of the advertisers parrying all attempts to displace advertisements by reading matter. We are lately getting out a third edition, to occupy the ground taken by the third edition of the Express which many persons have been till now obliged to read against their will. ${ }^{4}$ Our third edition is only a day or two old so that we can give no guess as to its success.

My best regards to Mrs. Bigelow. My wife and daughter send her their love and desire me to remember them most kindly to you.

\section{Yours faithfully \\ W. G. Bryant.}

P.S. Julia thanks Mrs. Bigelow for her pleasant letter and asks me to enclose the copy of a poem for which Mrs. Bigelow has enquired. ${ }^{5}$

W. C. B.

MANUSCRIPT: NYPL-GR DOCKETED: $\mathrm{W}^{\mathrm{m}}$. C. Bryant \& Co.

1. Bigelow had asked Bryant and Isaac Henderson whether, on his return from abroad in June 1860, he might occupy an office in the $E P$ building formerly rented to a Dr. Robinson. Bigelow to Henderson, $c$ December 10, 1859; Bigelow to Bryant, February 6 and 28, 1860, NYPL-BG. Christian G. Eckel, a lawyer, had offices at 53 Liberty Street during the period 1859-1861. Trow's New York City Directory for 1859, 1860, 1861 (New York: Trow $[1858,1859,1860]$ ).

2. Stephen Whitney, who died on February 16,1860 , at the age of 84 , was a wealthy New York merchant who was the last to keep a home facing Bowling Green, at the foot of Broadway.

3. George Wood (1789-1860, College of New Jersey [Princeton] 1808) had been a leading New York attorney and legal scholar.

4. The New York Express, started in 1836 as a Whig morning paper, had become an evening paper in 1858 with Democratic politics. Mott, American Journalism, pp. 261-262, 446.

5. Mrs. Bigelow's letter is unrecovered; the poem is unidentified.

1133. To Elizabeth D. Bancroft

Dear Mrs. Bancroft.

New York April 2d 1860

Mrs. Bryant is to have a box for tomorrow night in the Academy of Music, and as you like as little as she does the idea of waiting an hour and a half for the proceedings to begin I write this in her behalf to offer you a seat with her. ${ }^{1}$ If you do her the favor to accept it, you might either go with her from this place at a quarter past seven-or come directly to the box which is on the left hand as you go into the theatre from the front entrance -the first box you come to on the $2 \mathrm{~d}$ tier.-

I am, dear madam, faithfully yours

W. G. Bryant. 
P.S. My wife tells me to say that she hopes you will come here and go with her and Miss Sands-

W. C. B.

MANUSCRIPT: LC ADDREsS: Mrs. E. Bancroft.

1. On November 28, 1859, Washington Irving had died-in Longfellow's words, "In the bright Indian Summer of his fame." A few days later the New-York Historical Society, of which Irving had been one of the "earliest, most distinguished, and most cherished members," planned a memorial meeting to be held at the Academy of Music on April 3, 1860, his seventy-sixth birthday. There Bryant gave the principal eulogy (see Bryant, "Irving," pp. [95]-154). John Bigelow called this "the model of an eloge," and even Bryant's long-time political opponent William H. Seward saw it as " 'a monument of American literature." " Longfellow, "In the Churchyard at Tarrytown" (1876); Vail, Knickerbocker Birthday, pp. 395-398; Bigelow to Bryant, May 8, 1860, NYPL-BG; Seward to Bryant, quoted in Life, II, 134.

\section{To Edwin D. Morgan}

My dear sir.

New York April 11th 1860

You will not I am confident take it ill if I speak to you frankly in regard to what the people of New York expect from one to whom they have been proud to point as a man who would do his duty without flinching.

Those whose good opinion is worth having most earnestly hope that you will put your veto on the City Railroad bills which have just passed the legislature. ${ }^{1}$ It is not easy to conceive how intense is the disgust and how vehement is the indignation which these corrupt measures have awakened among that class of men with whom you agree in their views of the proper duty of legislators. They look upon the legislature as governed and managed by rogues, and in this I am fully of their opinion. I doubt, for my part, if we ever had so corrupt a legislature as we have at present and the imprecation

\section{"A plague on both your houses"2}

is in almost every man's mouth. The franchises given away by the railroad bills are the most outrageous misappropriation of public property that has ever been known in the annals of legislation on this continent-such I assure you is the general sentiment. On the prospects of the Republican party its effect is likely to be most disastrous. If the bills become a law the Republican party is annihilated in this city, and the action of public opinion here on the country cannot fail of being extremely unfavorable. On the prospects of Mr. Seward, the effect here has already been as bad as it well could be and nothing but the refusal of the Governors signature to these bills can prevent some of those who have been his best friends from giving way to an "irrepressible" desire to throw him overboard.

But party considerations are not the proper ones for deciding this question. The bills are unrighteous, against the interest and rights of the city; 
public opinion here is vehemently adverse to their passage-these are the true reasons for rejecting them. What good men here desire with all their hearts is an opportunity to celebrate another noble rebuke of legislative corruption by Executive integrity and firmness. ${ }^{3}$

\author{
I am dear sir \\ faithfully yours \\ W. C. BRYANT
}

MANUSCRIPT: NYSL AdDREss: To Governor Edwin D. Morgan DOCKeTED: $1860 / \mathrm{W}^{m}$ C. Bryant / Apl 11.

1. See 1119.4 .

2. Romeo and Juliet III.i.103.

3. These franchise bills passed the legislature over Governor Morgan's opposition and veto. Nevins, Emergence of Lincoln, II, 235; Van Deusen, Seward, p. 215.

1135. To George P. Morris ${ }^{1}$

Sir.

New York April 12th 1860.

The publication of Thanatopsis in the North American Review of which you speak, was the original one. My father found the fragment among some manuscripts which I had written several years before and left at Cummington, and took them with him to Boston where they were handed to those who then conducted the North American Review. The lines of which you speak, as being in a different metre, were another fragment, and were I suppose printed by mistake as part of Thanatopsis. The opening and concluding lines of Thanatopsis were written afterwards in $1821 .^{2}$

$$
\begin{aligned}
& \text { I am sir } \\
& \text { respectfully yours } \\
& \text { W. C. BRYANT. }
\end{aligned}
$$

MANUSCRIPT: HEHL ADDRESS: Gen Geo. P. Morris / Office of the Home Journal POSTAL ANNOTATION: [private].

1. From 1846 until shortly before his death in 1864, Morris (194.6) shared the editorship of the Home Journal with Nathaniel Parker Willis.

2. See 46.2, 73.2.

1136. To John Bigelow

Dear Mr. Bigelow.

New York April 13th 1860.

I wrote my last letter in such haste, that I omitted to do what was in my mind when I began it-that is to say to desire you to return my best thanks to $\mathrm{M}$. le Chevalier de Chatelain for the honor he has done my verses. To be translated into French by the translator of Chaucer is an honor in- 
deed. Please to thank him in my name for the new graces he has given to the Burial of Love, and to several others of my poems. Among these the version of The Strange Lady seems to me executed with particular skill. ${ }^{1}$

The two letters concerning which you inquire came to hand but they reached us at a time when [we] were puzzled to find room for the news of the day and for matters which the readers of the Evening Post must see. We are keeping them till the Spring flood shall have subsided, and when the muddy waters disappear we shall turn them in to make music in the regular channel. ${ }^{2}$

I admit that you have made your reasons for nominating Mr. Seward clearer by your explanation $-{ }^{3}$ but I do not care to enter into the argument now. His friends I have reason to believe are not dissatisfied with the course of the Evening Post, and whether he be nominated or not depends on causes of another kind. If you were here I think you would understand some parts of the question better than you can at a distance.

I hear that Mr. Thayer is a great deal better and he writes that he thinks of coming back to the office in May. This however, I do not think certain; for his cough it seems continues. Meantime he has made himself exceedingly disagreeable to Mr. Henderson by the manner in which he has talked to him-so that though I think very highly of Mr. Thayer's capacity as a purveyor of intelligence and other matters for a newspaper, I do not feel certain that it will be a pleasant thing for Mr. Henderson to see him in the office again. One of Thayer's offences though probably not the principal is his ambition to be regarded as the manager and director of the paper. ${ }^{4}$

We have your article on the paper duties which is timely and excellent and shall use it editorially-as I suppose you designed it to be used, or at least as I inferred that you were willing it should be used.

My regards to Mrs. Bigelow.

$$
\begin{aligned}
& \text { I am dear sir } \\
& \text { faithfully yours, } \\
& \text { W. C. BRYANT. }
\end{aligned}
$$

P.S. The Irving meeting was a great affair-so far at least as the concourse which attended was concerned-an immense audience and very attentive. Professor Greene's speech-the latter part at least was not heard-the audience was impatient for Everett, who delivered his remarks with more vehemence than usual. ${ }^{5}$

W. C. B.

MANUSCRIPT: NYPL-GR DOCKETED: W. C. Bryant \& Co / April 1860.

1. Bigelow had forwarded from London French translations of several Bryant poems by the naturalized British journalist Jean-Baptiste François Ernest de Chatelain (1801-1881). Bigelow to Bryant, February 28, 1860, NYPL-BG. Enclosed also was a letter from Chatelain to Fitz-Greene Halleck, accompanied by a translation of that poet's "Alnwick Castle." Bryant delivered this letter and its enclosure to Halleck, who was at home ill, and who remarked later, "I wish you had been present when he read the 
translation. His appreciation of the fun of the thing was visible in his eyes. They sparkled like stars in a frosty sky in the absence of moon and cloud: a study for an artist." Halleck to Bigelow, May 24, 1860, quoted in Bigelow, Retrospections, I, 265267. Chatelain also rendered several of Longfellow's poems into French. Nelson Frederick Adkins, Fitz-Greene Halleck: An Early Knickerbocker Wit and Poet (New Haven: Yale University Press, 1930), pp. 146-147; Longfeliow, Letters, III, 482; IV, 17, 63. Chatelain's translation of Chaucer was Contes de Cantorbéry (London, 1857).

2. Not yet having received Bryant's letter of February 6 (Letter 1126) when he wrote on the 28th, Bigelow had asked what his partner thought of his long letters for the $E P$ on the writings of Buffon and Beranger.

3. Apparently not yet fully aware of the growing interest in Lincoln in the East, after his Cooper Union address and subsequent speaking tour through New England, Bigelow wrote repeatedly of his conviction that Seward was the only reasonable choice for the Republican nomination for the presidency. The EP had, in truth, made little or no mention of Lincoln throughout March, and Bryant was equally noncommittal in his correspondence-though his distaste for Seward was quite evident. An unfortunate misreading, or oversight, caused Allan Nevins to write (Evening Post, p. 262) that Bigelow "had no use for Seward," and "saw in Lincoln the only hope of the party," while in fact, in the very letter Nevins cites, Bigelow said nothing of Lincoln, but insisted that Seward was the only acceptable candidate and would be nominated. Bigelow to Bryant, March 20, 1860, NYPL-BG.

4. Bigelow and Bryant seem to have agreed that William S. Thayer (924.4), who had served briefly as managing editor, was of more use to the $E P$ as a reporter. See Bigelow to Bryant, May 8, 1860, NYPL-BG.

5. Bryant's address at the Irving commemoration had been followed by several shorter ones, including those of Edward Everett and George Washington Greene (18111883), later the first professor of history at Cornell University. Vail, Knickerbocker Birthday, p. 398.

\section{To Robert Bonner ${ }^{1}$}

\section{Dear sir}

New York April $16 \quad 1860$

I am sorry I cannot give you the man's name at this moment. He is a person whose face I often see in the office-but whose name-though he gave it and I meant to remember it has wholly escaped my memory. Mr. Godwin knew him and spoke with him yesterday-and he is in the country. He may be in this morning-I will see him as soon as he comes in and find you the name. ${ }^{2}$

Yours truly

W C BRYANT

MANUSCRIPT: QPL ADDRESS: R Bonner Esq. DOCKETED: Apl 16/60 / Wm Cullen Bryant.

1. Robert Bonner (1824-1899) came to the United States from Ireland in 1839, and, after learning the printing trade on the Hartford Courant, moved to New York in 1844 to open a print shop. In 1851 he established the New York Ledger, a phenomenally successful weekly story-newspaper to which Bryant contributed a number of poems between 1859 and 1872, as well as a translation from the Spanish of Carolina Coronado's romantic novel, Jarilla.

2. The subject of Bryant's remarks is unidentified. 
1138. To Edwin D. Morgan

My dear sir.

I take pleasure in bearing my testimony to the merits of Mr. D. T. Marshall whose name, I understand has been suggested to you as that of a proper person to fill the vacancy in the Board of Police Commissioners. ${ }^{1}$

Mr. Marshall, I think, has eminent qualifications for that post. He is honest, just, quick-sighted, clear-headed, active and resolute. Without being contentious, he has a determined manner in all questions involving his integrity as a private or as a public man, which inclines less scrupulous persons to give way to him.

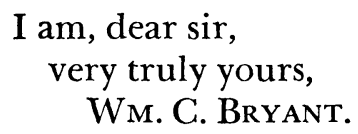

MANUSCRIPT: NYSL AdDRESS: To Governor E. D. Morgan. Docketed: W. C. Bryant / Apl $26^{\text {th }}$.

1. Marshall has not been further identified, and he seems to have failed of appointment.

1139. To John Howard Bryant

Dear Brother.

New York Apl. 27. 1860

I am willing that you should do almost any way with your debt to me -except that I do not like to own mortgaged land. If you want to keep the land would it not be better that you should give me a note at seven per cent interest, secured by a mortgage, for all that you would owe me? I will think however further of the matter-and I wish you would.

Your letter came to hand this morning. With regard to the Republican Manual, we decided not to publish it, the very hour that we [received?] ${ }^{1}$ your letter and that of your friend. We have always lost on such publications. ${ }^{2}$ But I put the letters into the hands of a person employed about our office, who promised to see the people in the office of the Tribune and ask if they would undertake it. They referred him to Greeley. Greeley could not be seen for some time, and only this moment have I been able to get his answer. He declines-observing that if the production had been offered gratuitously he might perhaps undertake it-but not otherwise. If your friend desires further communication with Greeley, he may address him directly.

As to the verses-I have been waiting for Mr. Godwin to return that I might ask him to do something with them. He has just returned this 
morning. I think them good and he has promised to see the Harpers Magazine men concerning them. I will write to you again about them. ${ }^{3}$

We are all passably well here, except Frances who is half dead with a severe influenza-or has been-and is fortunately coming to life again. The season is backward cold, sleety, and rheumatic. My kind regards to your wife and Elijah.

\section{Yours truly \\ W G BRYANT}

MANUSCRIPT: NYPL-BFP ADDRESS: JNo $\mathrm{H}$ Bryant Esq.

1. Word omitted.

2. For several years, at least-between 1839 and 1842-the $E P$ had published an annual Democrat's Almanac. See EP, April 24, 1840, and June-July 1841, passim; Letter 388. Neither John's letter nor that of his friend, unidentified, has been recovered.

3. Harper's New Monthly Magazine, founded in 1850, carried literary contributions by many prominent English and American authors. Though Parke Godwin apparently had no direct connection with the periodical, he was an intimate friend of George William Curtis (915.1), one of its principal contributors, with whom he had been associated in editing Putnam's Magazine. Godwin, "George William Curtis," in Commemorative Addresses ... (New York, 1895), pp. 3, 17-18. The verses referred to are unidentified.

1140. To Orville Dewey

New York, April 30, 1860

... If we will have you? Doctor,

"what words have passed thy lips unweighed!"

If the earth will have the spring-if the sunflower will have the sunshine-if the flock will have the grass. You might as well put an if between a hungry man and his dinner. You shall come to Roslyn, you and your Sultana, and shall be welcome, and treated en rois [like kings]. ${ }^{1}$ If I were writing for the press I should not say en rois, for in public I hold it my duty to maintain on all occasions the supremacy and sufficiency of the English language: but I have said en rois because it came into my head. Come on, and we will make the most of you both, and anybody else you choose to bring with you-that our poor means allow. You shall not be walked out more than you absolutely choose, nor asked to look at anything. You shall have full leave to bury yourself in books, or write, or think, or smoke away your time, and I will make a provision of segars for your idle hours, with the prudent toleration which the innocent have for the necessary vices of others. I have a coachman, and he shall take you about the country whenever you and Mrs. Dewey take a fancy for a ride. And having done this, I will neglect you, for I am afraid that is what you like, to your heart's content. And then, if-for I, too, must have my if-if you will only stay over 
Sunday, you shall be asked to preach by our orthodox Presbyterian minister, who inquires when Dr. Dewey is expected, for he wants to ask him to preach. Come, then, prepared for a ten days' sojourn, with a stock of patience in your heart, and a sermon or two in your pocket, of your second or third quality, for we are quite plain people here, and anything very fine is wasted upon us.

For any imperfections in my eulogy on Irving I beg you to consider the Historical Society as responsible; they put it upon me without consulting me; and at first I flatly refused, but I was afterward talked into consent. Besides the excuses of incapacity, unworthiness, and all that, I did not want the labor of writing the discourse. There has been no end of work with me the past winter. ... Among other symptoms of age, I find a disposition growing up within me to regard the world as belonging to a new race of men, who have somehow or other got into it, and taken possession of it, and among whom I am a superfluity. What have I to do with their quarrels and controversies? I, who am already proposed as a member of the same club with Daniel Defoe and Sir Roger L'Estrange. ${ }^{2}$ Is it fitting that, just as I have taken my hat to go out and join the Ptolemies, I should be plucked by the elbow and asked to read a copy of silly verses, and say whether they are fit to be printed? Besides, it seems to be agreed by everybody who is about my own age, or older, that the world is nowadays much wickeder than when they were young; and it is no more than it deserves to leave it to take care of itself as it can. But we will talk over these things when you come. ... .

MANUSCRIPT: Unrecovered TEXT (partial): Life, II, 134-136.

1. Dewey had written Bryant on April 28 (NYPL-BG) that he and Mrs. Dewey would visit Roslyn in the summer, provided Mrs. Bryant were well and they were wanted. The quotation is unidentified.

2. Daniel Defoe (1661?-1731) and Sir Roger L'Estrange (1616-1704) were controversial political journalists.

3. The Deweys apparently paid their visit about the middle of July. See Letter 1156; Dewey to Bryant, July 5, 1860, NYPL-BG.

\section{To Cassius Marcellus Clay ${ }^{1}$}

My dear sir.

New York May 4th. 1860.

I thank you for what you are so kind as to say concerning my discourse on Washington Irving. ${ }^{2}$

That your own life has not been allowed to pass in the same peaceful tenor as his ought not to excite in you any repinings. You have been placed by Providence in circumstances, for dealing with which you have shown a peculiar fitness. The great work of bringing a community prejudiced in favor of slavery to see their error, and to permit its evils to be freely dis- 
cussed has been laid upon you and you have shown yourself fully equal to it. ${ }^{3} \mathrm{He}$ may be esteemed a fortunate man who does not fall below the occasion to which he is summoned.

\author{
I am dear sir, \\ truly yours \\ W G Bryant.
}

MANUSCRIPT: New York University Library ADDREss: C. M. Clay Esqre.

1. Cassius Marcellus Clay (1810-1903, Yale 1832) was a Kentucky journalist and Abolitionist.

2. Clay's comment on the discourse has not been found.

3. In 1855 Clay had founded an anti-slavery community at Berea, Kentucky, where white and black children were educated together. In 1859 its residents were driven from the state by a mob, but Clay refused to be intimidated by his slaveholding neighbors. Nevins, Emergence of Lincoln, II, 109, 115.

1142. To James Grant Wilson ${ }^{1}$

Dear sir.

New York May 4th. 1860.

As I promised some days since, I have sent you by the mail of today, a copy of my discourse before the Historical Society.

$$
\begin{aligned}
& \text { I am, sir, } \\
& \text { very truly yours, } \\
& \text { W. C. BRYANT. }
\end{aligned}
$$

MANUSCRIPT: Andrew B. Myers ADDREss: Grant Wilson Esqre.

1. This is the earliest known evidence of an acquaintance between Bryant and James Grant Wilson (1832-1914), Scottish-born journalist whose chief claim to fame was a self-stated intimacy with the aging Bryant. To Wilson's sycophancy and ultimate negligence some of Bryant's friends attributed the poet's death in 1878. See, for example, John Gourlie to John Bigelow, July 1, 1878, Union College Library. See also Wilson's own account of Bryant's fatal injury in his "Memoir of William Cullen Bryant," The Family Library of Poetry and Song, ... . ed. William Cullen Bryant (New York: Fords, Howard, \& Hulbert [1880]), pp. 29-31.

1143. To Frances F. Bryant

Dear Frances.

Wednesday Morning.

New York May 9, 1860

I find the Bixby bill and money and have attended to paying the shoemaker. The Diary I do not see but I shall look further.

Last evening I went to look for Miss [Catharine] Sedgwick. I went to Harry's, his door plate was gone and nobody would answer the bell. I then went to Rackemann's. He had moved and with his family they said was at the Clarendon Hotel. In going to the Clarendon Hotel I stopped at Dr. 
Bellows's-he knew nothing about Miss Sedgwick's place of sojourn and had been looking for it in vain. At the Clarendon, they told me that Mrs. Rackemann was in Berkshire and he was out. I stopped at Mr. Valerios door. The girl said Miss Sedgwick was at Mrs. Carpenters No 58 in the same street. I went thither, it was Mrs. Faulkener's and Mrs. Robert Sedgwick came forward. Miss Sedgwick she told me was at Mr. Dudley Field's. I did not go further.

Soon after my return Mr. Charles Butler called and we arranged to go to his place on Friday if the weather be good. If I return in season I will come out to Roslyn on Friday afternoon. ${ }^{1}$

Yours ever

W G Bryant.

MANUSCRIPT: NYPL-GR.

1. In addition to the novelist Catharine Sedgwick and her nephew Harry, Henry Dwight Sedgwick (1824-1903), the persons named above who have been identified were Henry W. Bellows (734.3), Elizabeth Ellery Sedgwick (100.6; Letter 1014), David Dudley Field (492.4), and Charles Butler (946.2).

1144. To John Howard Bryant

Dear Brother

New York, May 14, 1860

It has struck me that if it would be profitable to cultivate the land of mine which is now grazed by those who have farms contiguous to it, it would answer for me to try my luck with your help. You say that you haven't the money at command which would be necessary for the cost of fencing and tillage. What do you say to my sending you all the money necessary and your taking charge of the matter and paying yourself out of the crop. Is there no rule of partnership applicable to such cases? If there is I am willing that you should go on under it and I will send all the funds which are necessary. Will you write to me on the subject as soon as you receive this letter?

We have had the same drought here which you have had in the west, only it came later. The grass suffers for want of rain-and some of the other crops. The season, however, is now rather forward.

We are all well and are again established in the country which is in all of its beauty.

As to your paying me for the money you owe me I am content that you should do it in your own way and time.

And regards to all.

Yours affectionately

W. C. BRyant.

MANUSCRIPT: BCHS TEXT: "Bryant and Illinois," 643-44. 
1145. To Charlotte Dana

My dear Miss Dana.

I came into town this morning thinking that I should stay overnight and meaning to call on you at 19 University Place. But matters are so arranged that I must return tonight and come in on Thursday morning, and I have been busy all the day till near the time of my departure.

It would give us great pleasure if you could come down to Roslyn if only for a night. There is a steamer, the Long Island which makes daily trips to Roslyn leaving James Slip at four o'clock in the afternoon, and coming back to town in the morning. You would have a pleasant sail at least and if Mrs. Ripley ${ }^{1}$ would come with you we should be all very glad to see her. James Slip lies a little above Peck Slip-between that and Catherine Street Ferry.

I wish very much to see you. I have a great many inquiries to make about your father and the rest of you. If you do not come out I shall look for you when I come to town again. My wife and Julia when I showed them your letter were very sorry that you could not find time to come and see them, and would send lots of love if they were with me. When you see your father please tell him that he should have come and made his abode with me till you should return. What is he doing that should keep him so close at home?

Yours truly

W. C. Bryant.

MANUSCRIPT: LH AdDREss: Miss Charlotte Dana. Docketed: From $W^{m}$ C Bryant / June 1860.

1. Probably Mrs. George Ripley (726.4).

1146. To Richard H. Dana

Dear Dana.

New York June 14th. 1860.

I hardly thought you would speak so well of my Eulogy on Irving as you have done. On such occasions we are apt to over praise and I was not sure that I had avoided that fault. The eulogy was well received, but Irving was a universal favorite and what I said was commended to men's kindness by the subject. But when you praise I know you mean it. ${ }^{1}$

With regard to giving letters to persons in England, I have always been embarrassed when asked to do it. The English are sometimes capricious in the matter of introductions and I am afraid of them. My literary aquaintances there are few. I have sought no man's aquaintance among them. I shall, however, rummage in my memory and see what I can do for your friend Mr. Dix. ${ }^{2}$ 
I have not written to you since the death of my little grandson. $\mathrm{He}$ was about three years old; quite a favorite in the family, waggish, playful, and of quick sensibilities. His loss was a great grief to all of us. I see that you too have had your losses by death. At our time of life we find the world becoming empty of those we love and filling up with strangers.

I have just called at No. 19 University Place to see Charlotte, and have found that she went to Boston yesterday morning. I have been in town but one day before since I learned she was here, and then I had to go back the same day, nor had I time to go up town to see her. I thought that I might persuade her to take a trip to our place on Long Island which at this season is pretty.

Your son Richard I suppose, when he returns, as I think he must, for after the hair breadth escapes he has made I account him pretty safe, for this journey at least, will make another book of travels. If it only contains personal adventures with nothing about the people and countries he has seen it will be interesting. But if he goes to Japan, he will be certain to give us a book which every body will read. I am quite curious to know how the Japanese will look seen through such eyes as his. ${ }^{3}$

My partner, Mr. Bigelow, who has been absent in Europe for a year and a half has just returned and I expect to have more leisure hereafterthough perhaps, for the last eight or nine months I have had as much as I ought to have. I sometimes think of visiting Boston again, but somehow I have a dread of Boston. To go to any country place is an entertainment to me; to go to a large town I find myself, for what reason, I can scarcely say reluctant. I shall not find Boston what it was when I knew it, and the change I am sure will not strike me pleasantly. In one respect it will affect me with sadness. Most of my old friends there and in its neighborhood are gone.

As you are mentioned in my Eulogy on Irving, I shall ask you to accept a copy of an edition got out by Putnam ${ }^{4}$ which I will send you by express.

Kind regards to Charlotte, and say to her, if you please, that I did not by any means intend to let her get out of town without seeing her.

I am, dear sir, faithfully yours W. C. BRYANT.

MANUSCRIPT: NYPL-GR ADDRESS: R. H. Dana Esq. ENDORSED: W $^{m}$ C. Bryant, June 14 / 60 / Ans. June 19 Published (in part): Life, II, 137-138.

1. After reading the address, Dana commented on Bryant's "naturalness, simplicity, and beauty of expression, tender thoughtfulness with all due praise, yet nothing in excess." Dana to Bryant, May 19, 1860, quoted in Life, II, 136.

2. Possibly John Homer Dix (1811-1884), a Boston ophthalmologist. No Bryant letter of introduction for Dix has been found.

3. Between July 1859 and September 1860 Richard Dana, Jr., traveled around the 
world, visiting Japan. Robert L. Gale, Richard Henry Dana Jr. (New York: Twayne [1969]), p. 85. Dana apparently published no account of this voyage. $1860)$.

1147. To Samuel A. Allibone

My dear sir.

New York June 15th 1860.

My opinion of the bad effect of composing at night upon the health, is founded principally on my personal experience. I find that it excites the nerves; that I cannot sleep after it, or that if I sleep I wake too early, and that after a short time it brings on weakness of body. I have heard many others complain that writing in the evening had the effect of making them sleepless afterwards. The early hours of the night I believe it is generally admitted are those in which we have the most refreshing and restoring slumbers.

Authors, it seems to me should have plenty of sleep, else the brain which is the organ brought into activity by their occupation will become over-worked. It should have ample time to rest and repair its vigor. Besides, it is in the latter part of the day that we generally make our most liberal meals, and to put the stomach and the brain to their hardest tasks at the same time is an indiscretion by which one or the other must suffer.

With regard to your own case I think you give too large a portion of time to your studies, and reserve too little for exercise society, your meals and your sleep. Nearly twelve hours a day are devoted, I believe, if I understand your letter, to your literary tasks. If Mr. Irving sometimes wrote fifteen hours a day I have the authority of his nephew that he suffered for it afterwards by languor listlessness and depression of spirits. Taking his literary life altogether he must have given much less time to the task of writing than you are doing for he sometimes did not touch his pen for many weeks together. ${ }^{1}$

You are familiar with the case of Southey who must have been as constantly at work as you are, who made change of subject stand him in the stead of recreation occupying himself with one kind of study in the morning, another at mid-day and a third at night, and yet who became prematurely superannuated. ${ }^{2}$ I remember that John C. Spencer an eminent lawyer of the New York bar, and at one time Secretary of the Treasury ${ }^{3}$ once told me that he was at work nearly all the time he was awake, busy in his professional or official labors. He was a remarkable example of energy and industry; he allowed himself no time for recreation or exercise, and always boasted of his excellent health, yet he suddenly became a mere wreck shattered both in mind and body and died I think not far from the age of sixty. 
You have now arrived at a time of life in which it seems to me that one should make some provision for a decline of the power of endurance. To refer to my own case, I have found great benefit from a regular system of chest exercises. I take them in the morning continuing them for about an hour. They favor a healthy arterial action, which you know accompanies the natural temperament of youth and cheerfulness.

Excuse this rather dogmatic letter which I might have made longer if I had been willing to bore you.

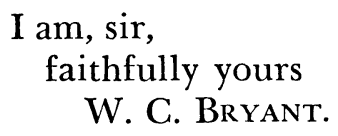

MANUSCRIPT: HEHL ADDRESS: S. A. Allibone Esqre.

1. Toward the end of his address on April 3, Bryant remarked of Washington Irving, "In the evening he wrote but rarely, knowing-so at least, I infer-that no habit makes severer demands upon the nervous system than this." Bryant, "Irving," p. 150. On May 23 Allibone had written Bryant (NYPL-BG) asking that he justify this statement.

2. The English Poet Laureate Robert Southey (1774-1843), whose literary output was prodigious, is said to have died from softening of the brain. 1843.

3. John Canfield Spencer (1788-1855, Union 1806), was also Secretary of War, 1841-

1148. To John Howard Bryant

Dear Brother

Office of The Evening Post, New York, June 161860

If I have not acknowledged having received your note of $\$ 4.480$ so promptly as you might have expected, it has been because I wished to inform you of my having seen the $\$ 250$ endorsed on the note which Fanny holds against you. I paid it to her when she was in town, and the note in the country. Since that time she has been in town most of the time, and when I have been in town she has been in the country. She has also been quite ill which delayed her going to the country. I shall attend to it immediately as she is at Roslyn and I go in an hour or two.

I enclose the note given by you \& Mr. Dee ${ }^{1}$ for $\$ 4.480$, with a $\$ 200$ note which has been paid. Let me know when you receive them.

Do you know of a good opportunity of investing a few thousand dollars-say from five to ten thousand? Please answer soon.

Yours truly
W G BRYANT

MANUSCRIPT: NYPL-BFP.

1. Unidentified. 
My dear sir.

\section{New York June 16, 1860.}

I was about to begin this letter by saying that I congratulate you on your nomination, ${ }^{1}$ but when I consider the importunities which will beset you as a candidate and the cares, responsibilities and vexations which your success will throw upon you, I do not congratulate you. It is the country that is to be congratulated. I was not without apprehensions that the nomination might fall upon some person encumbered with bad associates, and it was with a sense of relief and infinite satisfaction that I with thousands of others in this quarter heard that it was conferred upon you.

It is fortunate that you have never gathered about you a knot of political confederates who have their own interests to look after. You will excuse the frankness of an old campaigner who has been engaged in political controversies for more than a third of a century, if I say that I hope you will allow none to be formed around you while you are before the country as a candidate for the Presidency. I have observed that those candidates who are most cautious of making pledges, stating opinions or entering into arrangements of any sort for the future save themselves and their friends a great deal of trouble and have the best chance of success. The people have nominated you without any pledges or engagements of any sort; they are satisfied with you as you are, and they want you to do nothing at present but allow yourself to be elected. I am sure that I but express the wish of the vast majority of your friends when I say that they want you to make no speeches write no letters as a candidate, enter into no pledges, make no promises, nor even give any of those kind words which men are apt to interpret into promises. Several of our Presidents have had a great deal of trouble from this cause, and I suspect that Fremont if he had been elected would have had quite as much as any of them.

I trust that what I have said is no impertinence. I feel the strongest interest in your success, but it is only the interest of a citizen of our common country. What you do and say, concerns not yourself alone, but the people of the United States. I think you will be elected and I am anxious that you should go into the Executive chair with every advantage for making the most judicious and worthy appointments and lending your aid to the wisest and most beneficial measures. ${ }^{2}$

$$
\begin{aligned}
& \text { I am, dear sir, } \\
& \text { faithfully yours } \\
& \text { WM. C. BRYANT. }
\end{aligned}
$$

MANUSCRIPT: LC AdDREss: Hon. Abraham Lincoln. PUbLished: The Lincoln Papers, ed. David C. Mearns (Garden City, New York: Garden City Publishing Co., 1948), I, 257-258.

1. In Chicago on May 16 the Republican Party had chosen Lincoln over Seward 
as its presidential candidate. Three days later Bryant wrote, "It is written on the tablet of destiny that Lincoln is to be the next President," and, two days after that, "Whatever is peculiar in the history and development of America, whatever is foremost in its civilization, whatever is grand in its social and political structure finds its best expression in the career of such men as Abraham Lincoln." EP, May 19, 21, 1860.

2. In reply, Lincoln wrote Bryant on June 28 (NYPL-GR), "I appreciate the danger against which you would guard me; nor am I wanting in the purpose to avoid it. I thank you for the additional strength your words give me to maintain that purpose."

1150. To George P. Putnam ${ }^{1}$

My dear sir.

New York June $18 \quad 1860$

Will you be so kind as to send me six copies of my discourse on Irving -the smaller size?

Yours truly

W. C. Bryant.

MANUSCRIPT: UVa ADdREss: Geo P Putnam.

1. Publisher of Bryant's discourse on Irving; see 433.1, 1146.4.

1151. To Orville Dewey

Dear Doctor.

New York June 19, 1860.

Last evening I called at Dr. Bellows's house with the hope that I might see you but you had flitted.

When you and Mrs. Dewey shall have fixed the day for coming to visit us, you will of course let us know, that we may not have any engagement in the way. Our Presbyterian pastor, if pastor he may be called, who never holds a sheep-shearing, nor ever accepts the small clippings of a donation party, and yet who objects not to receive any handsome lock of wool that comes off in the brambles, is ready to resign his crook to you for one Sunday and trust you to lead his flock to

"fresh fields and pastures new,"1

and guide them to untasted springs. I hope they will

"bless their stars and think it luxury." 2

If they do not they will be sheep indeed, and deserve for the rest of their lives to be compelled to browse upon

"Darnells and all the idle weeds that grow,"3

and quench their thirst at puddles where the pigs cool themselves.

The sky over our heads is not brass quite-nor the earth under our feet ashes, but Roslyn suffers for want of rain, and if the showers do not 
fall soon the country will lose much of its beauty. The rains which are withheld from the region east of the Rocky Mountains have been poured down on the Pacific coast in California where the rainy season has lingered for weeks beyond its usual period.

Kind regards to the Doctorin as the Germans call the Doctors wife, and believe me

Yours ever

W. C. Bryant.

MANUSGRIPT: NYPL-GR ADDRESS: Revd Dr O. Dewey. PUblished (in part): Life, II, 138.

1. Cf. Milton, Lycidas 193: "To morrow, to fresh Woods, and Pastures new."

2. Addison, Cato I.iv.70.

3. King Lear IV.iv.5.

1152. To Richard H. Dana

Dear Dana.

New York June 22d 1860.

The letter to which you refer, written soon after the death of my little grandson, came duly to hand and if I have not thanked you for it already I do so now. ${ }^{1}$

With regard to my coming to Boston, I did not mean to say that I thought of it very seriously-if by seriously is meant that I regarded it as a thing very likely to take place this season. I am not much given to making little journeys, except from Roslyn to New York and back again. And yet I feel a certain yearning to see Boston and some of my old friends once more. It seemed to me possible that when my wife went to see her friends in Berkshire, I might make a deviation from the direct route and go or come by your good old town-but there are a great many things that strike us as pleasant to do and yet are never done, for somehow the fitting occasion never comes.

I should like I confess to see your place on the sea shore but whether I shall get there is a different matter-As for getting you to Roslyn I have almost given it up. There is room enough for you, chambers without guests, that would rejoice in your presence, and my wife and I find that we have fewer friends every year. I find it impossible to do what Dr. Johnson advised to keep my friendships in repair. ${ }^{2}$ I can set out a young tree where an old one died last year, but I cannot make a new friend fill the place of an old one.

I am glad to hear that your sister is doing so well. Say to all your family that I desire a place in their kind remembrance.

I am dear sir faithfully yours

W. C. Bryant. 
MANUSCRIPT: NYPL-GR AdDRESS: R. H. Dana Esqre. DOCKETEd: Bryant / 22 June 60.

1. See Dana to Bryant, February 25, 1860, Life, II, 133-134.

2. Bryant was fond of this advice of Samuel Johnson's; see Letter 481.

\title{
1153. To Robert Bonner
}

My dear sir.

New York June 27th 1860

I enclose you another poem for the Ledger. ${ }^{1}$ You will of course give me an opportunity of correcting the proof.

Yours faithfully

W. C. BRyANT.

MANUSCRIPT: QPL ADDRESS: R Bonner Esqre. DOCKETED: June 27/60 / W. C. Bryant.

1. The poem was probably "The Tides," printed in the New York Ledger, 15 (July 28, 1860), 1. See Poems (1876), pp. 365-366.

1154. To Gulian C. Verplanck ${ }^{1}$

My dear sir.

New York July 3d 1860

As your name is several times mentioned in the accompanying address I have thought that you might be not unwilling to do me the favor of accepting a copy of it. ${ }^{2}$

\author{
I am dear sir \\ truly yours \\ W. C. Bryant.
}

MANUSCRIPT: NYPL-Berg ADDREss: Hon G. C. Verplanck,

1. Though Bryant and Verplanck were no longer intimate, they met at meetings of the Sketch and Century Clubs quite often.

2. In discussing Irving, Bryant had reminded his listeners that Verplanck was one of the New Yorkers of Dutch descent who were at first irritated by the humorist's broad caricatures of their ancestors in A History of New York (1809). He referred also to biographical articles Verplanck had written for the Analectic Magazine while Irving was its editor in 1813-1814, and to Verplanck's intercession with Irving in 1832 to secure publication of Bryant's Poems at London. See Bryant, "Irving," pp. 114-116, 135.

1155. To John Howard Bryant

Dear Brother

Roslyn July 9 th 1860

Your letter of the $3 \mathrm{~d}$ instant reached me here on Saturday evening, and I [answer $]^{1}$ by the first mail that leaves this place-that is, on Monday. In regard to the purchases of which you speak, it seems to me that they offer all the advantages I could expect. ${ }^{2}$ The employment of an attorney to ascer- 
tain the goodness of the title is indispensable. I do it always, when I make a purchase of land here. You may draw on me for any amount within the sum I mentioned in my last -giving me information at the same moment, by letter, of what you have done. ${ }^{3}$

I am glad your crops are likely to come in so well. Here also they are good with the exception of hay-and that on my farm, though generally light elsewhere is more than an average crop.

Yours affectionately

W. C. BRYANT

P.S. As to fences I should of course be ready to bear any reasonable expense for putting them in order-though it is to be considered that bad fences abate something from the value of the land purchased.

W. C. B.

MANUSCRIPT: BCHS TEXT: "Bryant and Illinois," 644.

1. The printed text mistakenly has "answered."

2. In his letter dated Tuesday, July 3 (NYPL-BG), John reported finding several small farms of eighty acres each near Princeton, with buildings in fair shape for tenantry, at twenty dollars an acre. See Letter 1148.

3. Cullen Bryant's purchases of land in Bureau County, Illinois, in 1860, all presumably managed by John, totaled 729 acres costing $\$ 17,725$. "Bryant: Illinois Landowner," 12-13.

\section{To Orville Dewey}

My dear Doctor.

Roslyn July 9 th, 1860

I have your note appointing next week for your visit to Roslyn. ${ }^{1}$ No time could suit us better. After a long drought the earth has been saturated with rain. The burning of gunpowder-such is Espy's theory ${ }^{2}-$ on the fourth brought down the showers and the earth can hardly lose the reinforcement of freshness it has gained before you come. We should have been glad to have you in the season of cherries and roses which are just going out-the roses especially, but you shall be welcome to the raspberries gooseberries and verbenas with I hope a carnation or two. The church has been got ready for you-renovated as the Italians say-the ceiling as a country newspaper described it the other day, "painted in water colors"-that is to say, endued with a fresh coat of white-wash, the walls neatly papered, the pulpit and pews painted, and the floor neatly carpeted-and the segars are bought and ready for your smoking. I am told they smell of tropical sunshine and the Vuelta Abajo, but I know not, though I have been in San Antonio $^{3}-$ you shall judge. Have no apprehensions concerning the second sermon; the custom of the place tolerates but one on the Sunday.

If you do not like the word superfine applied to your sermons, exchange it for philosophical. Here in Roslyn we cannot all of us read, and 
yet we wear beards as long as any body. I wished merely to caution you against being misled by those external symbols of wisdom. What we require is milk for babes-the simplest rudiments of that divinarum rerum notitia [notion of divine things] of which you speak. And then our congregation is small, so that a great discourse will not be necessary. Our pastor will not run away you may be assured, but will sit beside you, both for his own edification, and to give his flock the assurance that what you shall set before them is good and wholesome. ${ }^{4}$

As for the visit you and your spouse must come as early and stay as long as you can. It will be time enough to think of a migration when you see the bottom of the segar box and no prospect of an immediate supply.

I sent you the other day a copy of my Discourse on Washington Irving, which as you were kind enough to commend, ${ }^{5}$ I thought you might consent to accept.

We are all as well as usual-in the patois of Berkshire, they say I believe usually well. My wife and daughter desire their love to you all-and when you are delivering that message please to add that $I$ also desire a place in their kind remembrance.

I am, dear sir, very truly yours

W. C. BRYANT.

MANUSGRIPT: NYPL-GR AdDREss: Revd. Dr. O. Dewey. PUBlished (in part): Life, II, 138-139.

1. Dewey to Bryant, July 5, 1860, NYPL-BG. (1841).

2. James Pollard Espy (1785-1860), American meteorologist, Philosophy of Storms

3. San Antonio de los Baños, Cuba. Bryant visited there in 1849; see Letter 675 . The Vuelta Abajo is a region in western Cuba famous for the production of tobacco.

4. Replying to Bryant's suggestion that he take the pulpit at the Presbyterian Church during his coming visit to Roslyn (Letter 1151), Dewey had written on July 5 (NYPL-BG), "I understand you, Monsieur, about the preaching, 'Don't bring any of your superfine sermons here!' Bah! I don't bring such any where. Your good pastor must not expect me to preach twin-making a convenience of me, to run away \& visit his father-in-law, or something-for I will do no such thing. I preach but once a day, in my own pulpit, you know."

5. In a letter dated April 28, 1860 (NYPL-BG) Dewey had remarked of the discourse, "Catharine Sedgwick says it is the best thing of the kind you have ever done. So do I."

1157. To George Bancroft

Dear Bancroft,

Roslyn August 1st 1860.

I have been thinking ever since I read the eighth volume of your history that I would write to thank you for the pleasure I had derived from 
it. My wife who has been dipping into it insists that I shall do this morning what I have delayed so long.

It is a great thing for a man to surpass himself; and this is what you have done. You have given us an Iliad with John Adams for the Achilles.

$$
\text { "Impiger, iracundus, inexorabilis, acer." } 1
$$

It had never struck me that this period of our history was susceptible of such an epic interest-but it was the part of genius to bring it out. The narrative parts and the delineation of characters are alike admirable.

I am dear sir truly yours

W G BRYANT

MANUSCRIPT: MHS ADDREss: Geo Bancroft Esqr.

1. "Diligent, irascible, inexorable, vehement." Horace, Ars Poetica 121.

1158. To John Howard Bryant

Dear Brother.-

New York Aug 2, 1860

I have this moment received your letter of the 30 th of July. ${ }^{1}$

As to the place in which the farms you purchase are situated I meant merely to say what I preferred-other things being equal, or nearly so. I, however intended to leave the matter to your judgement, expecting that you would do for me just as you would for yourself. The reasons you give for purchasing at some little distance from Princeton seem to me perfectly sound and convince me that what you have done is more for my interest than if you had purchased the high priced farms lying nearer. ${ }^{2}$

I hope therefore that you will go on as you have begun, and carry out the plans you have formed.

I am yours truly, W. C. Bryant

MANUSCRIPT: Mrs. Mildred Bryant Kussmaul, Brockton, Massachusetts AdDress: John H. Bryant Esq.

1. Unrecovered.

2. These purchases of July 18,21, and 31,1860 , totaling 304 acres at a cost of $\$ 9,755$, are detailed in "Bryant: Illinois Landowner," 12.

1159. To Christiana Gibson

New York, August 16, 1860

... Your summer must have been very agreeable if the season there has been like ours-temperate days, cool nights, almost perpetual sunshine, yet mild as the sunshine of early June. I desire nothing pleasanter in the way of weather than this summer has been on Long Island. Then the fruits have been so fine-plenty of strawberries, cherries of the finest, lingering 
into the latter half of July, till we became impatient to have them gone. Now the plums are coming in abundantly, almost for the first time, and basketfuls of juicy pears.

I was in town lately for two or three days, leaving Mr. William B. Ogden at Roslyn. When I returned, I found he had taken off Fanny and her husband, Julia and Bryant, ${ }^{1}$ to Mauch Chunk and Bethlehem. They were particularly delighted with Bethlehem and the Moravians, as you would be, for they are the most musical of all the little communities in the United States, and their litanies, which are addressed to the Supreme Being in choral harmonies peculiar to themselves, are very impressive. Fanny came back much improved in health. The Great Eastern has come and gone, but neither my wife nor I have seen it, so we shall have no cause to boast over you. I would not go where there was such a crowd, and the Great Eastern remains what my imagination pleases to make it. Those who have seen it have not that advantage. To them it is a circumscribed idea. ${ }^{2}$ Knowledge-particularly knowledge of the works of the human hand-is the great destroyer of the sublime....

MANUSCRIPT: Unrecovered TEXT (partial): Life, II, 139-140.

1. Fanny's eldest son, William Bryant Godwin.

2. The Great Eastern, largest steamship of the day, was causing a sensation in New York after its first trans-Atlantic voyage. It was even the subject of a comedy at Wallack's Theatre. In 1866 the Great Eastern was employed by Cyrus W. Field in laying the first transoceanic cable. See George C. D. Odell, Annals of the New York Stage (New York: Columbia University Press, 1931), VII, 208.

\section{To Robert C. Waterston}

Dear Mr. Waterston

Roslyn August 161860.

My wife and I give many thanks for the beautiful little book in which you have embalmed the memory of your beloved daughter. ${ }^{1}$ We prize it not only as a memorial of the virtues and graces which we had learned to admire and to love, but also as something which brings back and makes more vivid the recollection of pleasant days passed in the society of yourself and your family. You allude to them in a touching manner, but you can hardly know [how] much good your sympathy did us when on coming to Naples, you found us after an anxious winter, still anxious and uncertain as to the issue of the long illness with which my wife had suffered. You can hardly recollect that Sunday of which we speak with more emotion than we.

It seems to me that the collection of tributes to your daughter's memory is very happily made up- What you have said yourself is said in so becoming a manner; what your friends have said is said with so much feeling! ${ }^{2}$ Even those who are strangers to you all cannot but be interested 
in reading it. I have no doubt that you and Mrs. Waterston frequently recur to its pages, and find in them a certain consolation.

It is a satisfaction to me to know that you think so kindly of my eulogy on Irving. ${ }^{3}$ I undertook it most unwillingly. The Historical Society of which I was not then a member-they have made me an honorary member since-almost forced it upon me. They passed a resolution appointing me as the eulogist-and it was in all the newspapers, before I had any suspicion of what they were about. It is some comfort if you think that I did not commit an act of foll[y] in reversing my first determination which was to decline the task altogether.

I fear that we shall not be able to come to Boston this summer. I am busy with some little improvements on my place which must be executed while the season allows it. Otherwise I have leisure enough, and I should really like to see Boston again. So would my wife and as for Julia she is always ready for a journey.

But you if I rightly interpret your letter might find time to come to Roslyn, and nothing would give us all greater delight than to welcome you and Mrs. Waterston to our roof. The country is charming this summer fruitful and verdant, and we live in a rather pretty part of the country, among woods and waters and hills-not mountains-among winding roads and quaker houses. You and Mrs. Waterston would like the neighborhood I know. Our friends, Dr. Dewey and his wife, made us a visit lately. The Doctor preached at the invitation of the Presbyterian pastor and nobody discovered that he was not as good a Christian as the most orthodox. Only let us know at what time you will come and we will give you the whole season to choose from. Write as soon as you receive this and say that you and your better half will come, and if I might advise you will come soon. The season is remarkably cool, and comfortable for travelling, the nights never hot and the days charmingly temperate. Come while the hours between sunrise and sunset are still many, and the arrangements for travelling conveniently made. What do you say to the end of next week, or some time in the week following?

Julia is not here at this moment or she would join as my wife does in this entreaty and would desire her special love. She has made a little excursion to the Moravian town Bethlehem and its pleasant neighborhood. We expect her tonight and I wish I was able to gratify her with the news that you and Mrs. Waterston were soon coming to see us. My wife is well at present; a fall down some stone steps about four weeks since obliged her to keep her a bed a little while and her room for some days, but she is now wholly recovered. She sends much love to you both.

I am greatly pleased to hear of the token of reverence paid to $\mathrm{Mr}$. Quincy on the occasion of which you speak. It was well deserved and I hope he will live to receive many more such. 
A day or two since we were pained to hear of a calamity which has overtaken Mrs. Mackie whom you remember as Miss Ives when in our family at Naples. She has lost her first born, a fine little boy on whom she and her mother doted.

Kindest regards to Mrs. Waterston-and believe me ever and truly yours

W. C. Bryant

MANUSCRIPT: Stanford University Library ADDREss: Revd R C Waterston.

1. Robert C. Waterston, Helen Ruthven Waterston (Boston, 1860).

2. These tributes included a poem by Whittier, "Naples." See The Complete Poetical Works of John Greenleaf Whittier, Household edition (Boston and New York: Houghton, Mifflin, 1904), pp. 247-248.

3. Writing Bryant on July 26 (NYPL-BG) after receiving a copy of his Discourse on Irving, Waterston had called it "as discriminating and felicitous as any thing which ever came from his own pen."

\section{To John Howard Bryant}

\section{Dear Brother}

[Roslyn?] August 20, 1860

I wrote you not long since that I wish to invest only $\$ 20,000$ at the West-repairs and fencing included. I have since received your letter ${ }^{1}$ relating to that matter.

In the $\$ 20,000$ I do not mean to include the fencing of the lands which I already owned, and which you thought of taking to raise wheat upon. But all the new purchases with the incidental expenses I wish brought within that sum. ${ }^{2}$ Having that amount to invest, I wish to be understood literally that I desire literally to stop when it is exhausted, and make no subsequent additions at least till $\mathrm{I}$ am in funds to do so.

With regard to the letting of the farms which have been purchased or may be so I should like to know what percent on their value they generally bring when rented to good tenants in your part of the country. You think with me that the value of these lands will rise in the market-but what I wish to know is what income I may expect from them if they keep only their present value.

\section{Yours affectionately}

W. C. Bryant

P.S. On considering again what I have written, I wish to say that I do not wish you to decline making an advantageous purchase because it may oblige you to expend a few hundred dollars over the sum I have mentioned. Perhaps, even it may in the course of a few months become convenient for me to go as far as you mention-but it is not so now.

W. C. B. 
MANUSCRIPT: BCHS TEXT: "Bryant and Illinois," 645 .

1. Unrecovered.

2. In addition to the purchases outlined in 1158.2, on August 7 and October 7, 1860 , and March 27, 1861, John bought for his brother 585 acres for $\$ 9,570$. "Bryant: Illinois Landowner," 13.

1162. To Abraham Lincoln

My dear sir.

New York August 231860.

The bearer of this note is [Walter] Francis Williams Esqre. a gentleman of worth and talent connected with the Evening Post. ${ }^{1}$ Being on a tour to the western states he is naturally desirous to see the curiosities of the country and among others the next President of the United States. I have therefore taken the liberty of giving him this introduction to you.

$$
\begin{aligned}
& \text { I am, dear sir } \\
& \text { truly yours } \\
& \text { W C BRYANT. }
\end{aligned}
$$

MANUSCRIPT: LC ADDREsS: Hon Abraham Lincoln / Springfield / Illinois DOCKETED: W. C. Bryant. / Aug 23/60.

1. See 1119.10 .

1163. To J. Dennis Harris ${ }^{1}$

Dear Sir:-

Roslyn, Long Island, August 26, 1860

I have looked over with attention the letters you left with me, and return them herewith. It appears to me it will be very well to publish them. Of the Spanish part of the island of Santo Domingo very little is knownmuch less than of the French part; and the information you give of the country and its people is valuable and interesting.

$$
\begin{aligned}
& \text { I am, sir, } \\
& \text { Respectfully yours, } \\
& \text { W. C. BRYANT }
\end{aligned}
$$

MANUSGRIPT: Unrecovered TEXT: J. Dennis Harris, $A$ Summer on the Borders of the Caribbean Sea, with an Introduction by George William Curtis (New York, 1860), p. iv. ADDREsS: Mr. J. D. Harris.

1. A free black from North Carolina, Harris had first called on Bryant, then later written asking him to contribute a preface to his forthcoming book, intended to break down prejudices among North American Negroes against Spanish American countries as too tropical. Harris to Bryant, Cleveland, August 23, 1860, NYPL-GR. See descriptive note. 
1164. To A. D. Faulkner ${ }^{1}$

Sir.

The lines you quote were written by me, but the first line as you quote it contains a verbal error. Instead of

The crescent morn and crimson eve-

it should read

The crescent moon and crimson eve.

The lines form part of a poem entitled "The White-footed Deer." 2

Respectfully \&c

W. C. BRYANT.

MANUSCRIPT: University of Pennsylvania Library AdDREss: A. D. Faulkner Esqre.

1. Unidentified.

2. Poems (1876), p. 303.

1165. To Frances F. Bryant

Dear Frances.

New York Sept. 6. 1860.

Thursday morning

I got your letter of yesterday ${ }^{1}$ for which I thank you; but I am somewhat disappointed that you stay so long. Whether I shall come after you is a matter that requires consideration. I scarce believe that I shall. ${ }^{2}$

Yesterday I sent some grapes to Mrs. Smith the sick woman and the boy brought me word that she was getting better. Mrs. Nelson is ailing yet.

The evening before last we had the closing proceedings of a Sunday School Convention. A meeting was held in Mr. Ely's church; the middle pews were filled with the Sunday Scholars and the outside pews with the audience. Addresses were made by Professor Irvin, Mr. Hart, the Brittania Ware man of Burling Slip, and Mr. McCormick, the same who once visited us in company with Mr. Frank Ballard. Irvin was sensible, Hart funny and McCormick clever. I took Julia, Miss Jenny Hopkins, Minna and Annie. When asked which she liked best Annie answered "the funny fellow." Hart has a prodigious deal of a peculiar humor, and the entertainment was as amusing as a comedy. ${ }^{3}$

The same evening, a little past ten as I was going to bed, there was a pattering of rapid feet on the piazza, a pull at the bell and a thundering knock at the door. Every body got to the door as quick as possible and there were Minnie and Miss Gordon, ${ }^{4}$ who was scarce half dressed, and they had a mysterious story to tell. Bryant was absent-out of the house-not to be found. He was last seen in the parlor about eight o'clock having been out 
all day or nearly all in a boat with Willie Carpenter. The bolt of one of the shutters was shoved back, probably to allow him to return through the window. Miss Gordon had gone to bed early leaving him in the house, and now being apprized of his escape had rushed over to ask what was to be done.

After a good deal of consultation it was determined to send down to Frederick's-for Frederick had been sent in the evening to bring back the boat from where the low tide had obliged the boys to leave it, and also to send to Mr. Cairns's to see if Bryant was with Willy Carpenter. But first it was suggested that it would be well to make another search for the missing boy in every room in Fannys house.

Minna and Miss Gordon went back and found Bryant fast asleep on the sofa, rolled up in a shawl as snug as a bug in a rug-he had probably been there all the evening.

A long story about nothing-Fanny I hear came to town last night.

Regards to all- Yours ever

W. C. Bryant.

MANUSCRIPT: NYPL-GR ADDRESS: Mrs. F F. Bryant.

1. Unrecovered.

2. Frances was then visiting her sisters in Great Barrington.

3. Rev. Samuel R. Ely, D.D. (d. 1873) was the pastor from 1854 to 1870 of the Roslyn Presbyterian Church, which the Bryants attended when in the village. Goddard, Roslyn Harbor, p. 106. Except for Julia, Bryant's granddaughters Minna and Annie Godwin, his Roslyn neighbor Jenny Hopkins, and Frank Ballard (Letter 1489), those persons named in this paragraph are unidentified.

4. Probably the Godwins' nursemaid.

1166. To Hiram Powers

My dear sir.

New York September 13th 1860.

The bearer of this letter is Mr. William Livingston Alden of this city, a promising young member of the bar in this city ${ }^{1}$ who is about to sail for Europe with the intention of passing some time in its southern countries. May I ask of you to bestow upon him those attentions, which you take pleasure in showing your countrymen and for which I have myself been indebted to you. Be pleased to present my regards to Mrs. Powers and the young ladies.

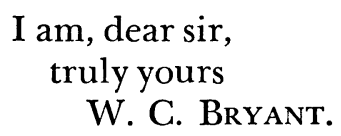

MANUSCRIPT: National Collection of Fine Arts ADDREss: Hiram Powers Esqre.

1. Alden (1837-1908), journalist and lawyer, is credited with introducing canoeing as a sport into the United States. 
1167. To Frances F. Bryant

Dear Frances.

Roslyn Saturday Sept. 14, 1860

I meant to have seen you off yesterday morning, but when I returned from the hill found to my surprize that I was too late.

Mrs. Nelson is the better for your prescription. Her complaint was dysenteric, and she finds herself relieved. Mr. Nelson, however, is not so well and does not work today. I have been to see him and have prescribed for him. I went with him to look at the well. He did not think that any thing was the matter with it nor did I. There was a little clear water at the bottom, and that was all that we could see. The smell was that of any wet place, so Mr. Nelson says. His complaint is different from that of his wife; it is a diarrhea. He complains of great weakness.

I saw Mr. Cairns yesterday. He inveighed at great length at what he called Mr. Willis's neglect of his children, saying he had just discovered that they got no whortleberries and no fish, and that he was just beginning to send them these things. ${ }^{1}$ It is curious enough that Mr. Willis who returned to Roslyn last evening, brought a fish to our house this morning and is to come and help eat it today.

The fair at Manhasset brought one hundred and sixty dollars. The price which is to be paid for the land selected as the site of the church is four hundred dollars. ${ }^{2}$

Mrs. Cairns has got home from Easthampton delighted with her visit. She says that Mr. Ely was welcomed with open arms by his old parishioners.

The horse is getting better; the barn is all but done; the new cook begins well. Fanny's new cook is much commended for her respectable appearance. I have written this morning to Mr. Waterston. ${ }^{3}$

Remember me kindly to Mr. and Mrs. Hopkins and to Mrs. Henderson, who I hope is better and to Hannah and the rest.

Yours ever,

W. G. BRYANT

MANUSCRIPT: NYPL-GR ADDRESS: Mrs. F. F. Bryant.

1. Mr. and Mrs. William Cairns of Roslyn (565.2) were the parents of the late Mrs. Richard Willis (1027.2). p. 107.

2. This was probably an Episcopal chapel, built in 1862. Goddard, Roslyn Harbor,

3. Bryant's letter to Waterston is unrecovered.

1168. To Cullen Bryant

Dear Nephew

New York September 18th 1860

Sometime since I forwarded to West Point by Express addressed to you a portable writing desk, which my wife directed to be purchased for 
you. ${ }^{1}$ At the same time I put into the post office a note addressed to you desiring you to inform us of its safe arrival. ${ }^{2}$ We have heard nothing of you or the writing-desk since. Will you be kind enough to write as soon as you receive this and let us know whether it came to hand or not. Write to Roslyn Long Island.

\section{Yrs truly \\ W G BRYANT}

MANUSCRIPT: NYPL-BFP ADDREss: Mr. Cullen Bryant / at the Military Academy / West Point / N. Y. postmark: [illegible].

1. See Francis Bryant to Cullen Bryant at West Point, cAugust 15, 1860, NYPL-GR.

2. Bryant's earlier note is unrecovered.

1169. To John Howard Bryant

Dear Brother.

New York September 22nd 1860

I enclose the receipt which you have written for.

As to the purchases I wish you to make the one for $\$ 1600$ by all means if you can. If you should be able to do this it will be well I think to let that be the limit of your purchases.

In case that cannot be done I think it might be well to buy the farm for $\$ 2300$ which you say is very cheap, unless some advantageous bargains for a smaller sum should come in your way. I leave that to your discretion.

We are all well. Frances has been generally better this summer than she was last year. We expect to go to Boston for a short visit next week.

The season is favorable. The grain is abundant and so is the fruit; the Indian corn good, and the potatoes fair. The political harvest is now promising. New York is for Lincoln; the other factions are discouraged.

Yours ever

W. C. BRYANT

MANUSCRIPT: Mrs. Mildred Bryant Kussmaul, Brockton, Massachusetts AdDREss: John H. Bryant Esqr.

1170. To Julia S. Bryant

Dear Julia

Roslyn Saturday Sept. 221860.

We go to New York on Monday and on Tuesday to Boston by way of Springfield, arriving at our destination a little before [five?] o'clock. If you could reach Boston about the same time it might be convenient; if not you might come on Wednesday morning. Should you get this in season I wish you would write immediately to Mr. Waterston, informing him at what time you will come. I know nothing about the most convenient way to get 
to Boston from Newport-Mr. Gillilan ${ }^{1}$-though I should be glad to spare him that trouble-will add to his other obliging civilities that of finding out for you and will see you on board the right train.

You speak in your letter to your mother, of going to the Prince of Wales Ball. If you wish to go, I do not wish to prevent you, though I feel an invincible aversion to going myself, the occasion being one which is not at all to my taste. I am perfectly willing to get a ticket for you if one is to be had, and another for any person who might go with you-but I do not think it worth while to pay the prices which I learn from the newspapers are now paid for them. I am not one of the committee and if I wanted to go should be at the mercy of those who speculate in tickets. I shall inquire how the matter stands when I go to town on Monday and will tell you all I can learn when I see you.... ${ }^{2}$

\section{MANUSCRIPT: NYPL-GR.}

1. Unidentified.

2. In the summer and fall of 1860 the eighteen-year-old Prince of Wales, later King Edward VII of Great Britain, visited Canada and the United States unofficially as "Lord Renfrew." While in New York briefly, he was entertained on October 12 at the Academy of Music. Although it is uncertain whether Julia attended, her father's distaste for such an affair seems to have been justified by the account given of it afterward by the Prince himself to his mother, Queen Victoria. "The great ball took place," he wrote, "but it was not successful. 3,000 people were invited and 5000 came. . . We arrived at 10 o'clock, and before the dancing had begun a great part of the floor gave way and it took two hours to set it right, so that dancing did not begin until 12 o'clock, and the crowd was so great that it was very difficult to move." Quoted in Sir Sidney Lee, King Edward VII: A Biography (New York: Macmillan, 1955), I, 103-104. Also see "The Ball to Lord Renfrew," $E P$, October 13, 1860. The complimentary close and signature to this letter are missing.

1171. To Robert Bonner

Dear Sir

[New York?] Sept 24th [1860]

I send you a poem for the Ledger. ${ }^{1}$ If you have occasion to send me a proof after 2 oclock P. M today and before next Friday-send it to me at Boston care of Rev ${ }^{\mathrm{d}}$ R. G Waterston

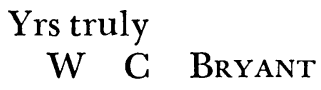

MANUSCRIPT: QPL ADDRESS: R Bonner Esq.

1. Probably "Italy," New York Ledger, 15 (October 20, 1860), 5. See Poems (1876), pp. 367-369. Bonner replied the same day (NYPL-BG), promising a proof in an hour or two, and adding, "I am glad that you sent me this poem, this morning, as in the same number... I shall have original poems from Willis, Morris, Saxe, Alice Cary, Mrs. Sigourney; besides contributions from James Buchanan, the President of the United 
States, Hon. Geo. Bancroft, Edward Everett, Henry Ward Beecher, Geo. D. Prentice, and others."

1172. To Richard H. Dana

\section{Dear Dana.}

Boston September 28th 1860 .

If I must go back to New York without seeing you, I assure you I shall be as sorry as you can be. ${ }^{1}$ At present your household is in such a state, that I could not think of adding to its inconveniences by coming to Manchester [Massachusetts], even if I had more time here-but I cannot wait for your invalids to be better, and you among the rest-for I have an appointment with a surveyor on Wednesday at my place on Long Island, when I am to adopt some plan for changing the public road from the front to the back of my house. I must therefore be off on Monday or Tuesday. However, I am determined to see you, if I live, after you come to town, and if I do not get a sight of you now, I shall be in Boston again before you get back to the sea shore. My wife who is as much grieved not to see you and Charlotte as I am, thinks she will come with me. She thanks your daughter with all her heart for her obliging letter,-but being somewhat of an invalid is withheld by still stronger reasons than I am from coming to your place in the country.

I should have come later in the season, but my wife dreaded the approach of cold weather. She is always fearful of getting chilled through which always makes her sick, and to tell the truth I hardly thought you would be out at Manchester after the middle of September.

However, I say again, it shall all be made right between us. I am getting to be a journalist emeritus, superannuated, I think they call it in the army-an unpleasant phrase, but one to the reality of which we must all come at last, if we do not go out of life prematurely. I had never so much leisure as now and I mean to make use of some of it to see you.

Kind regards to your daughter and sisters. My wife and Julia desire their love to you all.

Yours very truly

W. G. Bryant.

MANUSCRIPT: NYPL-GR ADDREsS: R. H. Dana Esqre. Docketed: Wm. C. Bryant, Sep 28 / 60 .

1. From September 24 to October 2 the Bryants visited the Waterstons at Chester Square in Boston. Bryant was kept busy. One evening Mrs. Waterston entertained a large company to meet him, and to celebrate the entrance of Giuseppe Garibaldi into Naples on September 7. Another day they visited Mrs. Waterston's father, Josiah Quincy, former president of Harvard, at his home in Quincy. Life, II, 140. And Longfellow is said to have made an "ineffectual effort" to induce Bryant to dine with the Saturday Club, Boston's prestigious literary rendezvous. Charles Francis Adams, Richard Henry Dana: A Biography (Boston and New York, 1890), II, 248. 
1173. To Robert C. and Anna Q. Waterston

New York, October 3, 1860, Six o'clock in the Morning

... We had the pleasantest journey from Boston to New York that could be imagined. A beautiful Indian summer's day, with floating clouds and a golden sunshine streaming between them through a soft autumnal haze, no dust, nor any other inconvenience. We reached New York in safety, Mrs. Bryant not much tired, at half past five, full of delightful recollections of our visit to Boston, and of your hospitality and extreme kindness. ...

MANUSCRIPT: Unrecovered TEXT (partial): Life, II, 140.

1174. [To Jacob Beakley?] ${ }^{1}$

My dear sir.

[Roslyn? cOctober 5, 1860]

I am fully sensible of the value of the compliment paid me by the Homoeopathic College in requesting me to deliver the address at the opening of their institution. I must, however decline the task. It is not often that I appear before the public in this way and when I do it is in obedience to a certain force of circumstances which almost amounts to compulsion. There is another circumstance which strengthens my aversion to such a display on this occasion - and that is that I have given sufficient attention to the homoeopathic system to be assured that I know little of it, and am quite incompetent to discuss it as it should be discussed.

Allow me in the meantime along with my thanks, to present to the Faculty of your institution my congratulations on the opening of a regularly organized place of medical instruction in the doctrines and practice of our school-a school the effect of which is not only greatly to lessen the [pain?] of human misery-but [promotive?] of the [interests?] of moralityYrs truly[unsigned]

MANUSCRIPT: NYPL-GR (draft).

1. Dr. Jacob Beakley was the first dean and professor of surgery at the New York Homoeopathic Medical College, established at Third Avenue and Twentieth Street on October 15, 1860. The college was an outgrowth of the New York Homoeopathic Society, of which Bryant had been the president in 1841. See 420.6; Letter 1508; Leonard Paul Wershub, One Hundred Years of Medical Progress: A History of the New York Medical College Flower and Fifth Avenue Hospitals (Springfield, Illinois: Charles C. Thomas [1967]), pp. 33-35.

1175. To James T. Fields

New York, October 9, 1860 ... I do not see how I can comply with the request you make. ${ }^{1}$ The Pierian spring on my grounds runs low; it is like the Fountain of the Virgin when 
I saw it at Bethlehem-only a drop oozing from the ground at a time. "Spare my age," as Pope says somewhere. . . .

MANUSCRIPT: Unrecovered TEXT (partial): Life, II, 141.

1. Then about to succeed James Russell Lowell as editor of the Atlantic Monthly, lately acquired by his publishing firm, Fields (973.1) had written Bryant on October 7 (NYPL-BG) soliciting a poem for the January number.

2. Cf. 1476.3. Apparently committed for the time being to offer his verses to the New York Ledger, Bryant made his first contribution to the Atlantic Monthly with "The Planting of the Apple-Tree," which was printed in January 1864. See Poems (1876), pp. 320-323.

\section{To Anna Q. Waterston}

My dear Mrs. Waterston.

Mount Savage Maryland October 15, 1860

We got your letter at New York just as we were setting out for this place on a visit to an old friend of mine a New Yorker who has been here for thirteen years. ${ }^{1}$ The "case" concerning which you express so much kind concern reached us safely in due time, but has been transported safely to this mountain region a hundred and eighty miles west of Baltimore among the Alleg[he]nies, the woods of which are now glorious with the hues of autumn. Here we are in the midst of forests of grand old trees, and grassy slopes, and deep valleys watered by shallow brawling streams and mountain summit overlooking mountain summit. We are in the Cumberland coal region, with mining villages around us and railway trains snorting and whistling as they bear their burdens to market. Today we have been on a visit to one of the coal mines, Mrs. Godwin and Julia and myself with our kind hosts; my wife I am sorry to say took cold on her journey and could not go- These mines are long black passages in the earth leading to low black chambers propped by posts where the workmen ply their sledges to break away masses of coal from the roof and walls. Out of some of these passages run little brooks yellow with alum and copperas, Stygian streams and the begrimed workmen black as Ethiopians bearing each a little crooked lamp in his cap look like horrid demons of the mine. At the end of one of these passages blazed and roared a fierce [fine?] fire of coal in a furnace reaching up through the mountain to the upper air, drawing after it a current of air from the entrance of the mine-with swarthy bare-armed workmen feeding the flames, so that the visitor might almost fancy he was going to be roasted alive-but it was only intended for ventilation.

Enough of this - It was very kind of your father and sister to think of visiting us on Chester Square, and it was our misfortune to have missed both this call and an earlier one. When you see your sister who wrote those kind words concerning us please thank her for them. We keep our visit to Chester Square among our pleasant memories- Best regards to Mr. Water- 
ston from my wife and Julia as well as myself-they send much love to you, and with me desire to be kindly remembered by your father and his amiable and excellent family.

[unsigned]

MANUSCRIPT: NYPL-GR (draft) PUBLISHED (in part, with changes): Life, II, 141.

1. Identified in Life, II, 141 as John A. Graham. See Letter 1177.

\section{To the Evening Post}

Mount Savage, Maryland, October [c18], 1860.

Before I say anything of this region, let me speak of what I saw at Baltimore. Our kind friend, at whose invitation we came hither, met us in that city and took us down to a point on the shore of the Patapsco, to see the new iron steamer which the Messrs. Winans have built upon a model of their own, by way of experiment, before making a trial of anything on a larger scale. Its shape has been compared to that of a segar; keel, sides and deck are round alike; and at each end it tapers to a sharp point. ${ }^{1}$ The length is a hundred and eighty feet, with a breadth of sixteen. It is formed of two hollow iron spindles, firmly connected with each other at the broad end by strong iron plates, and between these spindles plays a wheel with screw paddles, with which the steamer is urged forward. The blows of the sea from before or behind can take no effect upon it; all that the waves can do is to slide softly over it, and when they strike it on the sides they meet with much less resistance than in vessels of ordinary shape. It can never ship a sea.

A trial trip has lately been made with this steamer. "It ran round one of the fastest steamers in our harbor," said a gentleman to me, "playing about it like a shark about a sailing packet." I do not know what may be the expectations of the Messieurs Winans in regard to its speed, but the talk at Baltimore is of making the passage to Europe in four or five days, bearing with it the mails and specie and a few passengers. As I looked on this enormous iron shuttle, the velocity of which can be scarcely more affected by storms and head winds than that of a fish, and thought of it darting through the sea with the speed which is claimed for it, it occurred to me that if a sailing vessel should come in its way it must be pierced through and through, like a pine shingle by a bullet.

The railway which brought us to Mount Savage is one of the most picturesque in the United States. For more than a hundred and fifty miles it follows the course of the Potomac, winding as the river winds, making sudden turns around lofty crags, sweeping round the base of grassy hillsides, passing under old forests, now bright with their autumnal leaves, and sometimes coming out into fair open valleys. Harper's Ferry, where the Shenandoah comes breaking through its rocky pass to pour itself into the 
Potomac, would of itself be sufficient to give this railway a pre-eminence, were there nothing else worth looking [at] along its track. Here the train generally stops a few minutes, and the passengers alight to look at the majestic cliffs and to see the place which has recently acquired a new and memorable historical association by the strange adventure of John Brown. A hundred and eighty miles from Baltimore you reach Cumberland, one of the most beautiful sites for a town I ever saw. It lies on the north bank of the Potomac, amid a circle of lofty hills, clothed with forest and divided by half a dozen deep gorges. The town has one or two pleasant streets -the rest are shabby and unsightly. At Cumberland you leave the Baltimore and Ohio Railroad and enter a single passenger car at the end of a long row of empty coal wagons, which are slowly dragged up a rocky pass beside a shallow stream, into the coal region of the Alleganies [sic]. You alight among smoking furnaces and forges and vast heaps of cinders at Mount Savage, near the foot of the mountain range of that name, a village of four thousand inhabitants, gathered from various nations, mostly employed in the iron works and the mines, and living in dirty cottages. As you ascend from the village you perceive more and more of the beauty of the region. You are among deep winding valleys and broad mountain sides, forests of grand old trees and grassy fields, and at every step some new charm of the prospect opens upon you. From the mouths of coal mines on the mountains short railways descend to the village, down which rattle trains of trucks loaded with coal, the weight of which drags up the empty cars.

Our party made a visit the other day to a coal mine some three miles distant from Mount Savage. From one of the black entrances flowed a lively little stream with yellow waters, into which I dipped my finger to ascertain their flavor. It was acidulous and astringent, holding in solution both alum and copperas. Leaving this Stygian rivulet we came to another entrance, out of which a train of loaded trucks was passing, every one of which was attended by a miner, blackened from head to foot with the dust of his task, and wearing in front of his cap a small crooked lamp to light his way. As they emerged from the darkness they looked like sooty demons of the mine, with flaming horns, coming from the womb of the mountain. We now entered, each carrying a lantern, attended by a guide, whom the courteous proprietor directed to go with us. The vein of coal here is from eight to ten feet thick, and the passage is of that height, with a roof of glistening slate, propped in some places by wooden posts. Here and there, on each side of the passage, yawned chambers cut in the coal vein, and extending beyond the reach of the eye in the faint light of our lanterns. At length we heard the sound of sledges, and proceeding for some distance further came to the end of the passage, where the grimy workmen, each with a lamp in his cap, were driving wedges into the cracks and fissures of the coal, to separate it from the roof and walls. We saw several large blocks 
detached in this manner, the workmen jumping aside when they fell, and then we retraced our steps. Before returning to the entrance, however, our guides took us into a branch of the main passage, in which, after proceeding a little way, we heard a roar as of flames, and then saw a bright light before us. A furnace appeared, in which a fierce fire was blazing; the blackened workmen were stirring and feeding it, and a strong current of air rushing by us, went with the flames up the shaft, which reached to the surface of the ground above. This, we were told, was a contrivance to ventilate the mine. All the foul air, all the fire-damp and other noxious gases are drawn from the passages and chambers by this method, and carried up to be dispersed in the outer atmosphere.

On our way back to the entrance we perceived that the vein lay at just such an inclination as allowed the workmen to roll the loaded trucks by hand along an easy descent to the mouth, as I hear is the case with all the veins. We emerged in a pretty amphitheatre shaded by primeval trees, and saw what we had not before noticed-a proof that the approaching election of a President was as much a matter of interest to the people of this remote region as to you in New York. A flag was flying on a prodigiously tall pole near the mouth of the mine. It was a Lincoln and Hamlin² flag, they said, and the workmen had chalked the name Lincoln (only a little ill-spelled) on the sides of the trucks.

When I was in this region twenty-eight years since, they had not begun to work the mines of iron and coal. From the little town of Frostburg, where I then passed the night, a place lying high among the mountain ridges, where the winter comes early and lingers late, you now look down upon several mining villages. There are twenty-five of them in this coal region, and they are adding greatly to its populousness. New mines are opened from time to time, so that the mountains ere long will be pierced from side to side with these artificial caverns. A curious effect is observed in some of them; the little veins of water in the earth are collected in the drifts, or main passages, and issue noiselessly forth, with a current of the color of a porter bottle. Whether the soil above derives any advantage from this sort of underdraining I have not learned.

The population of the mining villages-though to this remark there may be exceptions-does not appear to me to be of the most hopeful kind. They owe little to the schoolmaster, and know so little of the advantages of education that they are not generally anxious to procure them for their children. Such of them, however, as are provident, invest their earnings in lands, and they and their children will ultimately pass into the agricultural class. The farmers whom the mining companies found here, living at great distances from each other, are ill-schooled, if schooled at all, and have fallen into habits of life only a little less rude, I should judge, than those of the miners. An increase of their numbers will have a tendency to raise the scale of civilization among them. They inhabit a region of considerable 
fertility; their fields yield good crops of wheat and other grains, the finest hay and a sweet pasturage for their herds. These farmers are Catholics, and almost in sight of where I write, in one of the greenest and pleasantest nooks of the hills, stands their old church and the house of their priest, surrounded by trees.

From the point at which I write many interesting excursions may be made. The visitor may follow my example in a drive to the neighboring mines, or he may pass to the Glades, as they call the country west of Cumberland on the railway, a tract of hills and dales covered with rich grass and grazed by numerous herds; or go on horseback to the pine woods of Mount Savage, and lose himself among trees with stems a hundred and fifty feet high; or proceeding a few miles further and crossing the Pennsylvania boundary, find himself among the Dunkers, a primitive and friendly people living in the Dutch Glades, who never suffer the razor to pass over their chins.

MANUSCRIPT: Unrecovered TEXT: EP for October 22, 1860.

1. In 1859 the engineers and inventors Ross Winans (1796-1877) and his son Thomas De Kay Winans (1820-1878) developed this cigar-shaped steamer, the prototype of later ocean liner hulls.

2. Hannibal Hamlin (1809-1891), a United States senator from Maine since 1848, was the Republican candidate for Vice President in 1860.

1178. To Charles Folsom ${ }^{1}$

My dear sir.

New York October 24, 1860.

I have this moment read your letter of the 17 th. having returned but a few hours since from a visit of a fortnight to Maryland.

Certainly I shall be very happy to say to any of my acquaintances, or to any body else who asks me for my opinion, that I have not the least [doubt?] ${ }^{2}$ that any young girl educated in your family would be educated in the very best manner. I should hardly confine myself to what you request-namely that I should refer the inquirer to some of my friends in your quarter.

Use my name therefore in any circular or announcement that you may think fit to draw up.

Present my kind regards to Mrs. Folsom, and believe me, dear sir, truly yours.

W. C. Bryant.

MANUSCRIPT: Boston Public Library address: C. Folsom Esq.

1. Bryant's co-editor on the United States Review in 1826-1827; see Vol. I, 16, and 
passim. Folsom, whose letter of October 17 is unrecovered, had been librarian of the Boston Athenaeum from 1846 to 1856.

2. Word omitted.

1179. To Townsend Ward ${ }^{1}$

Sir.

New York October 24. 1860.

I am sensible how much I lose in declining the invitation of the Historical Society of Pennsylvania to be present at their dinner on the 8 th of November. My engagements, however, are such that I must forego the pleasure of being one of the guests, and it only remains that I make my best acknowledgements to the Committee for the honor they have done me.

$$
\begin{aligned}
& \text { I am, sir } \\
& \text { very respectfully yours } \\
& \text { WM. C. BRYANT. }
\end{aligned}
$$

ManusCRipt: HSPa adDREss: Townsend Ward Esq. / Secretary of the / Committee \&c.

1. See descriptive note.

1180. To Abraham Lincoln

My dear sir.

New York Nov 1, 1860.

It has been intimated to me that it is the intention of some of your friends here, particularly certain persons concerned in commerce and the transactions of Wall Street to request you to make some statement in the newspapers, which shall as they say "quiet the public mind"-some declaration of your intentions and the policy you mean to pursue if elected President. It is too late to do this before the election, but they would be satisfied if it were done immediately afterwards. ${ }^{1}$

I write to say that I am confident that this is not the desire of the most discreet of your friends. Such a declaration would be regarded as a concession to our political adversaries. They would consider it as something extorted by the violence of their attacks and would be encouraged to continue them. They would not be satisfied with any thing that could be said and would clamor for something more decidedly in their favor.

This is I think the view taken by the coolest heads among the Republicans here, and you will excuse me, I hope, for stating it-since I do so with the view of preventing any mistake on your part as to the wishes of your friends here. ${ }^{2}$

I need not say that we are perfectly sure of New York-the state. ${ }^{3}$ Yours very truly W. C. BRYANT. 
MANUSCRIPT: LC ADDRESS: Hon Abraham Lincoln.

1. As the campaign of 1860 neared a close, southern warnings of national disunion if Lincoln were elected impelled some Republican leaders to deny the probability of Abolitionist action by his administration. Thurlow Weed urged Senator Seward to make a "soothing speech" suggesting that the party was "all for peace, union, and prosperity." This Seward did, before a great crowd at the Palace Garden Music Hall in New York on November 2, promising "no acts of aggression against the slave states." Van Deusen, Seward, p. 235; Nevins, Emergence of Lincoln, II, 300-301, 306309. Pressure on Lincoln to temporize continued to build up; he was urged to deny the implications of his "House Divided" speech of 1858 and to promise no interference with slavery. Horace Greeley hinted in his New York Tribune that the southern states might be allowed to secede peacefully, as the Buchanan administration had implied.

2. On November 12 Republican Senator Preston King of New York (810.2) wrote John Bigelow, "I think there is no danger of Lincoln making any declaration to anticipate the day of his inauguration, but I am glad that Mr. Bryant wrote-for we cannot be too secure upon such a point." Bigelow, Retrospections, I, 316.

3. On November 6 Lincoln carried New York, as well as all other free states. The next day, from Princeton, Illinois, John Bryant wired his old legislative companion, "Bureau Co. sends greetings with twenty three hundred majority for Lincoln Lovejoy and Liberty." Telegram in Lincoln Papers, LC. Owen Lovejoy (748.5) was re-elected to Congress for a third term.

1181. To an Unidentified Correspondent

[New York? cNovember 1?, 1860]

I have your letter ${ }^{1}$ informing me that I have been designated by a state Convention of the Republican party as one of their candidates for elector through whom the votes of the state are to be cast for Lincoln and Hamlin, as President and Vice President. I accept the nomination with which they have honored me and if elected shall faithfully fulfil the trust reposed in me.

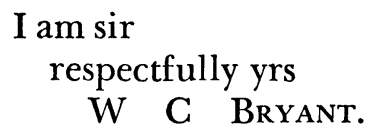

MANUSCRIPT: NYPL-GR (draft).

1. Unrecovered.

1182. To Abraham Lincoln

My dear sir.

New York November 10th 1860.

You will not I hope find what I have to say unseasonable or intrusive; if you should, you will of course treat it as it ought to be treated.

I have no doubt that you are already receiving frequent suggestions respecting the formation of your Cabinet when you take the Executive chair. It is natural that your fellow-citizens who elected you to office should feel the greatest interest in the selection which you may make of the men 
who are to be your confidential advisers and your special assistants in the administration of public affairs. You will therefore, I am sure, readily pardon the exhibition of some zeal in regard to this subject, even if it should go somewhat beyond the limits of a well-bred reserve.

You have numerous friends in this quarter, and they include some of the most enlightened and disinterested men in the Republican party, who would be infinitely pleased if your choice of a Secretary of State should fall on Mr. Salmon P. Chase of Ohio. He is regarded as altogether one of the noblest and truest among the great leaders of that party.-as a man in all respects beyond reproach-which you know can be said of few public men. $\mathrm{He}$ is a man of a well-stored mind and large experience, able, wise, pure, fair-minded, practical,-as he has shown in his administration of the affairs of the state of Ohio-never the associate of bad men, nor likely to advise the employment of such men in any capacity. ${ }^{1} \mathrm{~A}$ cabinet with such a man in its principal department, and colleagues worthy of him in the others, would command the immediate confidence of the country.

Of course, I do not expect that you will make any reply to this letter. I pray you to receive [it] ${ }^{2}$ as a proof of my desire for the success of your administration and give its suggestions such weight as you may think they deserve.

$$
\begin{aligned}
& \text { I am, sir, } \\
& \text { sincerely yours, } \\
& \text { W. C. BRYANT. }
\end{aligned}
$$

MANUSGRIPTS: LC (final); NYPL-GR (draft) ADDREss: Hon. Abraham Lincoln PUbLISHED (from preliminary draft): Life, II, 150.

1. Bryant's inexorable opposition to the Seward-Weed faction in New York politics had won him a position of national leadership among those Republicans who had blocked the nomination of Seward for the presidency, and were as adamant against allowing him to dominate Lincoln's cabinet. With such former Free Soil leaders as David D. Field and Gideon Welles, the EP editor was determined to strengthen Lincoln's resolve against the temptation to compromise with southern radicals, by bringing Chase, the former anti-slavery governor of Ohio, into close proximity with the President. Hendrick, Lincoln's War Cabinet, pp. 95, 126; Nevins, Emergence of Lincoln, II, 444446.

2. Word omitted.

\section{To Robert Bonner}

My dear sir.

New York Nov. 15, 1860

I called at the Ledger Office yesterday to speak with you concerning the enclosed manuscript, but was not so fortunate as to find you in.

You may remember that some time since I sent you a story which I had been desired by a lady to submit to your consideration, and that you paid her liberally for it. The accompanying sketch is from her pen. ${ }^{1}$ I do 
not wish to trespass upon your good nature or to make that liberality an occasion for further demands upon it. If the sketch pleases you-and I think it is pretty well done-and if moreover you think it is worth any thing, I should be glad to have her paid according to the rate you pay for such contributions. If you do not want it or do not care to pay for it, I beg you to deal with it as you deal with what is sent you from other quarters and send it back to me without ceremony.

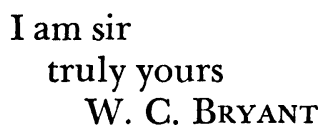

MANUSCRIPT: QPL ADDRESS: R. Bonner Esqre / Editor of the Ledger.

1. The lady and her sketch are unidentified.

1184. To Robert C. Waterston

Roslyn Long Island November 16, 1860.

My dear Mr. Waterston.

Roslyn is so pleasant just now that I am wishing every day that you would come and see it. I am fearing, all the time, that the next week will envy the beautiful weather of this. This sweet sunshine cannot always last; the season of blustering winds and lowering skies is at hand; the roses that are now so fresh in my garden cannot flaunt there long; they will be surprized some night by a deathly frost and the green grass that I see from my window must become of a russet hue. I hope you will be here before the ground stiffens into stone.

We returned long since from our little tour to the interior of Maryland, pleased with our visit, and my wife all the better for it. Julia is now off again, for a little while, on a visit to a friend in Baltimore. When you come this way do not think of visiting Roslyn on the first Monday in December, for then you know I must be in Albany to give my vote for President and Vice President of the United States. With that exception choose your own time, only, if you happen to be very sure of it beforehand, be so kind as to let me know also.

I suppose you rejoice, equally with myself, that the cause of justice and liberty has triumphed in the late election. I am sorry, on their own account that the people of South Carolina are making so much fuss about their defeat, but I have not the least apprehension that any thing serious will result from it. ${ }^{1}$

Kindest remembrances to Mrs. Waterston and yourself and from me to Mrs. Waterston.

I am, dear sir, faithfully yours Wm. C. BRyant. 
MANUSCRIPT: Brown University Library ADDRESS: Revd. R. C. Waterston.

1. Bryant's guess was scarcely prophetic! Within a few days of Lincoln's election a States Rights flag was flown over public buildings in Charleston, South Carolina's two United States senators resigned, and the legislature passed a bill calling a secession convention and another authorizing the governor to spend $\$ 100,000$ for arms. Nevins, Emergence of Lincoln, II, 318-320.

1185. To John Howard Bryant

\section{Dear Brother.}

Roslyn Nov. 29th 1860.

I have your letter of the 19 th and the map of Bureau County, ${ }^{1}$ for which I thank you-as well as for the statement of the purchases made on my account. On the map are five squares colored blue to represent the new purchases-in the statement six purchases are mentioned. Are two purchases of 160 acres each comprehen[d]ed in one square-that having the name of Starkweather? There is also a purchase of 160 acres not paid foris that in Bureau County? ${ }^{2}$

I shall direct your draft for fences \&c to be paid. You must begin to think what compensation I shall make you for the trouble you have taken and let me know.

We are rejoicing here over the election but we are not without our anxieties lest the cabinet may not be what we could desire. As to disunion nobody but silly people expect it will happen. The course of trade however, has been greatly disturbed by a panic which somehow or other has been got up, while the country is in a condition of the greatest prosperity. The panic has occasioned great losses and embarrassments.

Our autumn has been delightful with the exception of three very cold days last week and a cutting wind that seemed to come from the very pole. As to the summer I never knew a pleasanter one in any country that I have seen. Kind regards to Harriet and Elijah, in which my wife joins- Julia is on a visit to Baltimore.

Yours affectionately

W. C. Bryant.

MANUSCRIPT: NYPL-BFP.

1. Unrecovered.

2. See Letters $1155,1169$.

1186. To Frances F. Bryant

Dear Frances.

Albany Tuesday morning December 4th, 1860

I came up yesterday by the Harlem railroad, leaving New York at half past ten. It is pleasanter than the Hudson railroad; the cars more roomy and not so crowded and the motion much easier. 
Elias Leavenworth ${ }^{1}$ was on board and one of the electors whom he knew got in with us at a place called Bedford. I am at Congress Hall with a comfortable room with a fire.

Today we do nothing but organize and fill vacancies. Tomorrow we vote for President \&c. I shall come down to New York tomorrow if I can, and if it does not oblige me to arrive late in the evening.

Yours ever W. C. B.

MANUSCRIPT: NYPL-GR.

1. Bryant's early law clerk; see 123.1; Letter 431 .

1187. To Robert Bonner

Office of the Evening Post New York, Dec. 8th 1860

My dear sir.

A poem for the Ledger. ${ }^{1}$ Can you oblige giving a proof today before one o'clock? If not please send it to me at Roslyn Long Island-

Yours truly

W. C. BRyANT.

MANUSCRIPT: QPL.

1. This was doubtless “A Day-Dream," written at Naples in May 1858, and published in the New York Ledger, 16 (January 5, 1861), 8. See Poems (1876), pp. 369-371.

1188. To Abraham Lincoln

My dear Sir.

New York Dec. 25, 1860

The rumor having got abroad that you have been visited by a well known politician of New York who has a good deal to do with the stock market and who took with him a plan of compromise manufactured in Wall Street, it has occurred to me that you might like to be assured of the manner in which those Republicans who have no connection with Wall Street regard a compromise of the slavery question. ${ }^{1}$ The feeling of decided aversion to the least concession was never stronger than it is now. The people have given their verdict and they do not expect that either their representatives in Congress or their politicians out of Congress will attempt to change or modify it in any degree. The restoration of the Missouri Compromise would disband the Republican party. Any other concession recognizing the right of slavery to protection or even existence in the territories would disgust and discourage the large majority of Republicans in this state and cool their interest in the incoming administration down to the freezing point. Whatever else be done the slavery question, so 
far as it is a federal question must remain as it is or the Republican party is annihilated. Nor will any concession of the sort proposed satisfy the South. South Carolina cannot be hired to return to the Union by any thing short of the removal of all restraints on the African slave trade. ${ }^{2}$ To do that would convert at once into friends of the Union, a class of the southern politicians who are doing a great deal to foment the discontents of the South and might effect what the Wall Street managers hope to bring about by restoring the Missouri line, and giving protection to slavery south of it.

You will excuse me if I say a word concerning the formation of the Cabinet. I am glad to hear that it is decided to have regard in its composition to that part of the Republican party which is derived from the old democratic party. It would be most unfortunate if the Cabinet were to be so constituted as to turn the policy of the administration into the old whig channels. To instance a single branch of that policy-the policy of restraints upon trade for the advantage of the manufacturers. We of the old democratic party who are the friends of free trade are perfectly willing that this should be regarded as an open question, but we shall be placed in immediate antagonism to the administration, the moment this is made a part of its governing policy. A bigot to protection placed at the head of the Treasury department would at once open a controversy on that question which would be carried on with zeal, perhaps with heat. ${ }^{3}$

You will I know excuse these suggestions. If not wise they are at least disinterested. I have not, that I know of the remotest interest in politics except that our country should be governed with wisdom and justice, and with the allowance of the largest liberty in all things consistent with good order. You will receive perhaps from me letters in favor of persons desiring some office under the federal government or see my signature to recommendations got up by them or their friends. I pray you, in all these cases to believe, that no personal favor will be conferred on me, in any possible instance by bestowing the desired office on the person whom I may recommend. What I say for them should be taken as my opinion of their fitness and nothing more.

$$
\begin{aligned}
& \text { I am, dear sir, } \\
& \text { very truly yours }
\end{aligned}
$$

W. C. BRYANT.

P.S. In regard to the slave-trade, the zeal for its restoration arises from its profitableness. Large capitals are invested in it and it is the most lucrative of all branches of commerce.

W. C. B. ${ }^{4}$

MANUSCRIPT: LC ADDREsS: Abraham Lincoln Esqre / Springfield / Illinois pOSTMARK: Roslyn / N. Y. / DEC / [25?] ENDORSED: Wm C. Bryant / Compromise - protection - personal. PUBLISHED: Spivey, Bryant Cautions and Counsels Lincoln, pp. 4-5.

1. Thurlow Weed-the "well known politician"-having failed to beguile Lincoln into calling on his defeated rival at either Auburn, New York, or Chicago, visited the President-elect in Springfield, Illinois, with the aim of securing for Seward a dominant 
role in the new administration. Weed was also determined to foreclose cabinet appointments of former Democrats Salmon Chase, Gideon Welles, and Frank Blair by proposing instead southern Whigs disposed to follow Seward in conciliating the South. And just three days before his December 20 visit, Weed had repeated in his Albany Evening Journal his earlier proposal to restore the Missouri Compromise line of 1820, allowing the spread of slavery into new territories. See Hendrick, Lincoln's War Cabinet, pp. 114-120; Nevins, Emergence of Lincoln, II, 393-396.

Bryant and his New York associates were the more indignant over this visit because Weed had got to Lincoln before they did. On December 2 Senator Lyman Trumbull of Illinois told Lincoln of a call Bryant and two others had paid him in New York, expressing opposition to Seward's entering the cabinet, and reporting the formation of a committee to convey their opinion to the President-elect. See draft letter, Trumbull to Lincoln, Chicago Historical Society.

2. On December 20 South Carolina had adopted an ordinance of secession from the Union.

3. It was known that Seward and Weed wished to see Simon Cameron (1190.2), Pennsylvania manufacturer and high-tariff politician, made Secretary of the Treasury. Hendrick, Lincoln's War Cabinet, pp. 113-114.

4. In his reply to this letter on December 29 (NYPL-GR) Lincoln assured Bryant that, in the choice of a cabinet, "I promise you that I shall, unselfishly, try to deal fairly with all men." But he was less than frank in a flat statement that the "well known politician' ... did not press upon me any such compromise as you seem to suppose, or, in fact, any compromise at all." See also Nevins, Emergence of Lincoln, II, 396-397.

1189. To Robert C. Waterston

Roslyn, ${ }^{1}$ December 26,1860

Dear Mr. Waterston,

I do not write this to answer your most agreeable letter, ${ }^{2}$ which I got a few days since, but to say that I have sent you by express a copy of my Discourse on Irving for the Massachusetts Historical Society, and along with it a copy of an Illustrated Edition of my Forest $\mathrm{Hymn}^{3}$ for you and Mrs. Waterston.

With regard to the Discourse it seems to me that I promised when in Boston to send a copy to the Historical Society. ${ }^{4}$ If I did I wholly forgot it. Could you tell me from any recollection you have whether I said I would send a copy to any other of the collections I visited in your company. If I did I shall be somewhat mortified, but the mortification may do me good.

With regard to the "Hymn" I am sure that you and Mrs. Waterston will like the illustrations. They are done by a young artist named Hows, the son of an Englishman whose name you may have seen as an elocutionist in the newspapers. The young man was born in this country-he is but a youth still-and is a diligent student of our woods, and an enthusiast in his profession. ${ }^{5}$ The publication was got up without any agency of mine; the first I knew of it was when the bookseller brought the drawings to me, and asked my permission to publish the verses in a volume by themselves, which, as you may suppose, the beauty of the designs readily induced me to give. 
I hope you and Mrs. Waterston have had a cheerful Christmas, and I wish you may enter next Tuesday upon a happy year. Looking at the date of my letter I see that I have written New York when I should have written Roslyn, for my wife and I are passing a rather solitary Christmas, in sight of the tides wrought into white caps by the northeast wind dashing at the foot of our garden, with flocks of screaming seagulls sitting on them, or wheeling in the air, and a drowsy warmth within our dwelling.

I have seen Whittiers beautiful lines and have them by me, to republish as soon as the holidays are over. ${ }^{6}$

The madness of the South astonishes me. Some good people in your state-several of them I know to be good people-others are a little below the average standard of goodness-have issued an address the purport of which seems to be that the Massachusetts Personal Liberty law is in fault and ought to be repealed. ${ }^{7} \mathrm{I}$ am astonished as much at the remedy they propose as at the audacity and wickedness of the secessionists. They care very little for the Personal Liberty laws. Nothing will purchase the acquiescence of South Carolina in the Union, short of repealing all our laws against the slave trade and allowing it to be carried on without obstruction. There is no traffic so profitable, and as I hear there are large capitals invested in it in Salem as well as New York. I do not say that the importers of slaves from Africa are the only instigators of the southern revolt, but I am sure that if this most lucrative branch of commerce could be freely pursued, some of the most active and noisy of the rebels would be among our most loyal citizens. Chief Justice Shaw's prescription is as wise as a proposal to set a broken leg by giving the patient a dose of valerian. ${ }^{8}$

My best regards to Mrs. Waterston. My wife, who is quite well and active desires love to you both-Julia is in town.

\section{I am dear sir, very truly yours W. G. BRYANT}

MANUSCRIPT: NYHS ADDRESS: Revd. R. C. Waterston.

1. Bryant mistakenly wrote "New York"; see letter text.

2. Waterston had written Bryant on December 19 (NYPL-BG) saying he and his wife had hoped to visit the Bryants in the fall. $[1860])$

3. A Forest Hymn. With illustrations by John A. Hows (New York: J. Gregory

4. In thanking its author for a copy of the discourse on Irving, Robert Charles Winthrop (1809-1894, Harvard 1828), president of the Massachusetts Historical Society, wrote Bryant, "It gives me peculiar pleasure to unite in giving the unanimous vote by which you have succeeded to the place of Irving on the roll of our old Historical Society." Winthrop to Bryant, February 27, 1861, quoted in Life, II, 136-137.

5. John Augustus Hows (1832-1874, Columbia 1852) of New York was primarily a wood engraver and book illustrator. $D A A$.

6. See 1160.2.

7. During the 1840 s and 1850 s, in the face of the federal fugitive slave laws, most 
northern states passed legislation "designed to prevent kidnapping and to safeguard the rights of free Negroes." Massachusetts provided defense for fugitives at public expense. Russell B. Nye, Fettered Freedom: Civil Liberties and the Slavery Controversy, 1830-1860 ([East Lansing] Michigan State University Press [1963]), pp. 275-276.

8. Lemuel Shaw (1781-1861, Harvard 1800) was chief justice of Massachusetts, 1830-1860. Shaw held that the Massachusetts Personal Liberty Law was in conflict with the United States Constitution and federal laws, including the Fugitive Slave Law. On December 18, 1860, his name headed a petition from a number of prominent men which was published in daily newspapers, urging repeal of the Personal Liberty Law on the grounds that it violated the compact between Massachusetts and other states, and prevented federal officers from performing their duties. Frederic Hathaway Chase, Lemuel Shaw, Chief Justice of the Supreme Judicial Court of Massachusetts, 1830-1860 (Boston and New York: Houghton, Mifflin, 1918), pp. 177-179. 